\title{
Eastern Promises: Poland's Role as a Regional Actor in the European Union's Eastern Policy-- the Example of Belarus
}

\author{
Max David Reinke \\ West Virginia University
}

Follow this and additional works at: https://researchrepository.wvu.edu/etd

\section{Recommended Citation}

Reinke, Max David, "Eastern Promises: Poland's Role as a Regional Actor in the European Union's Eastern Policy-- the Example of Belarus" (2012). Graduate Theses, Dissertations, and Problem Reports. 731. https://researchrepository.wvu.edu/etd/731

This Thesis is protected by copyright and/or related rights. It has been brought to you by the The Research Repository @ WVU with permission from the rights-holder(s). You are free to use this Thesis in any way that is permitted by the copyright and related rights legislation that applies to your use. For other uses you must obtain permission from the rights-holder(s) directly, unless additional rights are indicated by a Creative Commons license in the record and/ or on the work itself. This Thesis has been accepted for inclusion in WVU Graduate Theses, Dissertations, and Problem Reports collection by an authorized administrator of The Research Repository @ WVU. For more information, please contact researchrepository@mail.wvu.edu. 
Eastern Promises: Poland's Role as a Regional Actor in the European Union's Eastern Policy- the Example of Belarus

\author{
Max David Reinke
}

Thesis submitted to the College of Arts and Sciences at West Virginia University in partial fulfillment of the requirements

for the degree of

Master of Arts

in History

Robert Blobaum, Ph.D., Chair

Joshua Arthurs, Ph.D.

Elizabeth Fones-Wolf, Ph.D.

Department of History

Morgantown, West Virginia

2012

Keywords: Poland; Belarus; European Union; Foreign Policy; Democratization 


\title{
ABSTRACT \\ Eastern Promises: Poland's Role as a Regional Actor in the European Union's Eastern Policy- the Example of Belarus
}

\author{
Max David Reinke
}

The present thesis will analyze Poland's current and potential role as an effective regional actor in mediating the European Union's (EU) relations with its easternmost neighbors. In order to most accurately assess this, this thesis will examine Poland's relationship with Belarus, specifically democratization efforts and forging a strong, resolute association with the European Union. Being a successful post-communist transition state and recent EU Member State, Poland has for some time seen itself to be the most-qualified country to bridge Eastern and Western Europe. Belarus in particular is a country of concern for the Polish government because it is a bordering country with a long historical relationship to Poland and contains an ethnic Polish minority. This thesis will discuss and evaluate the previous and current initiatives the European Union and Poland are taking in Belarus, their level of success, and will postulate who would be poised to be the most efficacious (external) player in the country's progress towards democratic consolidation and good governance. By using the example of Belarus this thesis will also expand the current literature on the ability of Member States (particularly newer ones) to influence policymaking in Brussels. 



\section{TABLE OF CONTENTS}

INTRODUCTION: No Man is an Island Regionalism in the EU .......................... 5

CHAPTER 1: Historical Dynamic of Poland and Belarus ............................. 13

I. The Grand Duchy of Lithuanian and the Polish Lithuanian Commonwealth .... 15

II. Legacies of Polish dominion during Russian rule in Belarus ................... 17

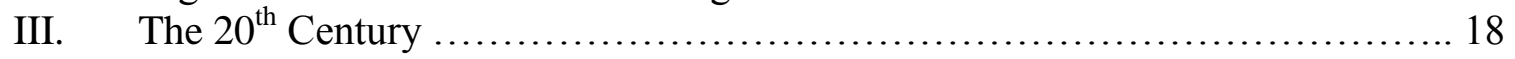

IV. Conclusions ........................................................... 24

CHAPTER 2: Polish-Belarusian Relations since the Collapse of Communism .................. 26

I. The Immediate Post-Soviet Cooperation ............................... 26

II. Lukashenko and the decline of progress in Poland-Belarus Relations ............ 29

III. Issues of the Polish Minority in Belarus ...................................... 32

IV. The 2010 Belarusian Presidential "Elections" ............................. 34

V. Polish Foreign Aid to Belarus ........................................ 36

VI. Polish assistance to NGOs and other institutions ........................ 40

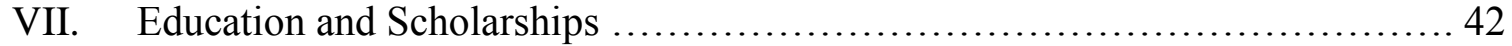

VIII. Conclusions ................................................... 43

CHAPTER 3: The EU's Past, Present, and Potential Strategies towards Belarus ............... 46

I. European assistance to Belarus during the 1990s ......................... 47

II. Belarus as part of the European "Neighbourhood" ............................ 48

III. The Eastern Partnership: promises and compromises .................... 52

IV. The Polish factor in EU-Belarus relations .............................. 55

V. The 2011 Polish Presidency of the EU ................................ 56

VI. The Warsaw Summit and Belarus's withdrawal from the EaP ................. 58

VII. Conclusions ..................................................... 61

CONCLUSIONS: A European Future for Belarus? .................................... 66

I. Lukashenko's future as the president of Belarus: prolonged but in peril? .... 67

II. Prospective programs for facilitating democratization in Belarus ............ 70

III. Final thoughts .................................................. 72

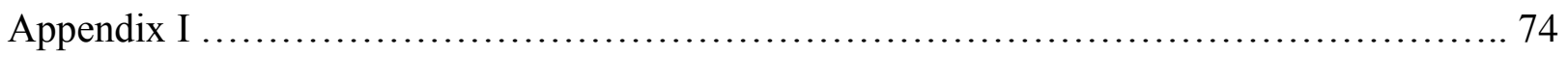

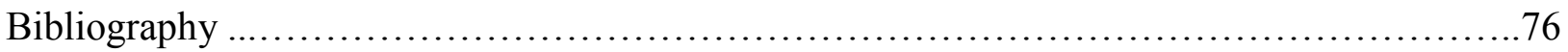




\section{INTRODUCTION: NO MAN IS AN ISLAND \\ Regionalism in the European Union}

The European Union (EU) is an unprecedented experiment not only in Europe but also in the world. What started as a vehicle for economic cooperation among an exclusive cluster of Western European states has evolved into a supranational global actor. Both internally and externally, the process of EU enlargement has had a dramatic effect on the European Union. The boundaries of the EU have expanded in nearly every direction, and as a result, the European Union has had to adjust accordingly. This transformation has not only affected the internal structure of the EU- the Union's approach towards neighboring countries also had to evolve. The English poet John Donne once said that "no man is an island." Like man, no country in today's integrated and globalized world can thrive while isolated from others. For Europe, its bordering countries are important for security, transport, trade, markets, and stability. As the EU continues to grow, so do its responsibilities. The European Union is now an important global actor; therefore EU external policy is an exigent concern for Brussels. The provisions for a Common Foreign Security Policy, first introduced by the Treaty of Amsterdam in 1997, was the first step in the European Union adopting a concrete strategy for external relations. Also in the Treaty of Amsterdam was the Union's commitment to upholding democratic principles and the protection of human rights and certain fundamental freedoms. As the "Arab Spring" democratic revolutions in North Africa and the Middle East have demonstrated, the Union intends to make the respect for democratic principles a primary component of foreign relations as well as internal affairs. Furthermore, these revolutions have proven that what happens outside of the EU has a direct impact on the European Union. Because of this, the EU's actions (or inactions) in these circumstances have both immediate and far-reaching consequences.

Since the European Union expanded into Central and Eastern Europe through the first decade of the new millennium, the EU's territorial border is now flush with Russia and its influence extends into the Caucasus region and Central Asia. While these countries tend to be less developed, poorer, and politically unstable, the potential for these states and their people cannot be discounted. Due to the abundant natural resources prevalent in this region, Europe's energy security is contingent on healthy relations with Russia and other surrounding countries. It 
is therefore essential for the European Union to formulate a comprehensive eastern policy. During the Cold War many of these countries were a part of the Soviet Union, so they were unquestionably within the Russian sphere of influence. Even though the Cold War ended, Europe's engagement with the region has changed little. How can this divide between the EU and the east be bridged, and who can most effectively do it?

Poland is keen to be this bridge. Taking into account a number of factors, it would make sense that Poland would be poised to take on this role as connecting Eastern and Western Europe. Poland's ability to adopt a free-market democratic system is widely credited as being one of the most successful in Central and Eastern Europe. Therefore, it has recent and firsthand experience with the trials and tribulations of transforming a planned economy and authoritarian government into a liberal, western-style democracy and functioning market economy. Poland was the largest country in the $2004 \mathrm{EU}$ enlargement and is currently the sixth most populous country in the European Union. Additionally, being a Slavic, Central European state, Poland has historical, linguistic, and cultural ties to several countries in Eastern Europe. While these indicators would make it clear that Poland would be a very suitable country to bridge the European Union with the east, has Poland capitalized on this opportunity?

This thesis will argue that as a successful post-communist transition state, Poland has the opportunity to become a major player in the EU's external relations with Eastern Europe. To prove this, this thesis will analyze both Poland and the EU's development assistance methods with the Eastern European country of Belarus. By inspecting and evaluating assistance to Belarus, particularly democratization efforts, at both the bilateral and European level, this thesis will highlight whether Poland has the ability to mediate a strong relationship between the EU and Eastern Europe, including Belarus.

Why Belarus? Belarus has been a peculiar state in the post-communist era. While the fall of the Soviet Union and the end of the Cold War triggered a host of new democratic governments around the world, Belarus remains unaffected by this wave of democracy. While the question for many post-communist European states is the level of progress in transitioning to democracy, Belarus's current political and economic status has barely changed since its days as a Soviet republic; Belarus's democratic maturation has stagnated and the country has slipped back into authoritarianism. Additionally, while many formerly communist states eagerly oriented their foreign policy to be pro-western and pro-European (Poland, perhaps, the most so), Belarus's 
leadership continues to look eastward towards the Russian Federation for political, economic, and military cooperation and support. Because of these factors, Belarus has been pejoratively dubbed "the last dictatorship in Europe." For much of the EU's history, Belarus has been on the fringe of policy concerns. With the Union's enlargement in 2004, however, Belarus borders three EU Member States. What is the nature of the European Union's presence in Belarus, how efficacious has the EU been in forging a stable association with Belarus, and in future initiatives who specifically would be the most effective (external) player in aiding democracy and good governance in Belarus?

Scholarly studies on Member States' influence in shaping EU foreign policy are few and far-between. While attention to the Union's external policy is steadily increasing in both academic and political discourse, the scope of the conversation usually pertains to the "big picture." All too often the focus is how Brussels should act towards clusters of countries with varying political structures, histories, and cultures. While this would be an appropriate analysis for a traditional relationship between two states, the sui generis nature of a supranational institution's interaction with third-party countries requires an alternative perspective. In 2008, Dr. Nathaniel Copsey from the University of Birmingham and Dr. Karolina Pomorska from the University of Maastricht wrote a paper titled "Poland's Power and Influence in the European Union: the case of its Eastern Policy." Presented at the American Political Science Association conference in Boston, the paper concluded, after meticulous research, that even though Poland aspires to play a hands-on role in EU policymaking towards the east, it has been ineffective in achieving this goal. Some of the reasons the two authors cited for this shortcoming are Poland's inefficient national bureaucracy, the unpreparedness of Polish diplomats to network when they first arrived in Brussels, the adverse stereotypes of Poles (and at that time the negative press coverage of the conservative Kaczyński government) in Europe, and an overall lack of clout of Poland compared to more established Member States like France and Germany. ${ }^{1}$

While the conclusions derived from this paper present an accurate assessment of Poland's inability to rise in the EU hierarchy, much has happened since 2008 that needs to be taken into consideration. In terms of EU policy, the most ambitious program in Eastern Europe undertaken by the EU ever, the Eastern Partnership (EaP) had not been officially launched at the time of

\footnotetext{
${ }^{1}$ Nathaniel Copsey and Karolina Pomorska, "Poland's Power and Influence in the European Union: the Case of its Eastern Policy" (paper presented at the annual meeting of the American Political Science Association, Boston, Massachusetts, August 30, 2008).
} 
Copsey and Pomorska's paper. Additionally, Poland had yet to hold the Presidency of the Council of the European Union, a position that would make Poland a strategic director of EU policy. The Presidency requires years of planning and is not only an excellent learning experience on how to handle the inner-workings of the Union but also showcases the strengths and leadership capabilities of individual Member States in the Union.

Changes occurred not only in Poland's relationship to the European Union but also within Poland itself. The new Foreign Minister, Radosław Sikorski, has ushered in a number of changes within the Ministry of Foreign Affairs (MFA). Such innovations include consolidating diplomatic missions abroad while bolstering strategically important embassies (such as in Brussels, London, and Kiev), digitalizing the Foreign Ministry and its offices abroad, and absorbing the office dedicated to Poland's EU integration into the MFA. These structural, organizational, and technological upgrades are all designed to streamline Poland's foreign representation and allow Poland to be more efficient in its endeavors abroad. Also cited in Copsey and Pomorska's article was Poland's weak economy translating into insufficient leverage at the EU level compared to other powerful European states. During the European economic crisis in 2009, Poland was the only country in the European Union that did not undergo a recession and in fact experienced economic growth. Poland continues to grow, and advocates stronger intra-EU trade, completing the Single Market, and other pro-European solutions for stimulating the European economy.

In addition to contributing to the literature pertaining to the evolution of EU external policy and Member States' influence on said policy, this thesis also aims to provide an up-to-date and comprehensive assessment on Belarus. With Belarus and its relationship to the EU, the literature available in English is minimal compared to other Central and Eastern European states. Based on the preliminary research conducted for this thesis, the literature that is published covers such topics as the formulation of Belarusian national identity, Belarus's historical and modern relationship with Russia, and the country's controversial president, Aleksandr Lukashenko. Furthermore, there are a number of works in scholarly journals pertaining to issues such as the construction of civil society in Belarus. However, there have been several recent developments in Belarus that are important in understanding the Belarus's struggle for democracy and the international response. The appallingly illegitimate December 2010 presidential "election" in Belarus and the brutal crackdown on civilians that ensued, Belarus's souring relationship with 
Russia, and the economic/ currency crisis are all significant game-changers for EU-Belarus relations. With the European Union's very nascent Common Foreign and Security Policy coupled with the diversity of those countries deemed to be in the European neighborhood, what would be the best solution: centralized decision-making and execution or addressing and managing relations at a regional level?

The conceptual underpinning of this thesis to examine regional actors and their influence on EU policy was inspired by the article "The Age of Nonpolarity" by the President of the Council of Foreign Relations, Richard N. Haass. Also written in 2008, Haass theorizes that since the beginning of the twentieth century, the balance of power in the world has shifted in several distinct patterns. Before the World Wars, global politics was multipolar, with the concentration of power held by various empires and states around the world. After 1945, however, the world became decidedly bipolar, with the United States and the Soviet Union competing for power and influence, particularly in the developing world. With the disintegration of the Soviet Union, the US emerged as the world superpower and enjoyed two decades as the leader of the new, unipolar world order. Now, it appears as if power is once again spread out amongst a myriad of different entities to the extent that no one agent or agents dominate the international arena. In essence, the world has become nonpolar. ${ }^{2}$

While nonpolarity may appear identical to multipolarity, the emphasis in a nonpolar world is not concentration of power and influence, but rather the distribution of power and influence. Also, the decline of states as the primary decision-makers in global systems is also an important aspect in the nonpolar paradigm. States now compete with international organizations, NGOs, multinational corporations, and interest groups for power at every level. While power is now in the hands of a variety of newcomers, Haass observes that the world is also seeing a decrease in the efficacy of traditional superpowers and witnessing a surge of regional powers. The historical global leaders like the United States, the United Kingdom, and Japan are being rivaled by countries like Brazil, China, India, Nigeria, and Turkey. On every continent, new countries are growing to be regional powerhouses and expanding their sphere of influence through political, economic, and social instruments. Much like Venezuela in South America or Pakistan in the Middle East/ South Asia, this thesis predicts that Poland will rise as a regional power in the EU and particularly in directing EU policy towards Eastern Europe.

\footnotetext{
${ }^{2}$ Richard N. Haass, "The Age of Nonpolarity: What Will Follow US Dominance?" Foreign Policy, May/ June 2008.
} 
Addressing regionalism in the creation and implementation of EU policy corresponds well with the salience of regions in the evolution of the European Union. While the EU is increasingly adopting responsibilities that are normally reserved for nation-states, EU structural reforms reflect a trend towards decentralization and emphasizing Europe's regions. All actions taken by the European Union uphold the principle of subsidiarity, which dictates that decisions made in Europe should take place and be implemented at the lowest level of governance possible. The Committee of the Regions, also established in the Treaty of Amsterdam, allows local and regional officials access to European institutions and policymakers in Brussels. The European Commission created and continues to finance programs such as Interreg and ECOSOuverture that promote partnership and information exchange amongst regions in Europe. Billions of euros every year are directed towards regional development funds; structural funds like the Union's Cohesion Fund and the European Regional Development Fund are second only to agricultural subsidies in the amount of money allocated to the European budget.

Much of this effort in promoting a "Europe of the regions" is concentrated on regions within Member States. However, in the European Union, macro-regions are also growing in number, size, and influence. Cross-border regions in Europe are steeped in cultural, historical, and ethnic traditions. SaarLorLux, Cataluña, Basque Country, and Rhône-Alps are all recognized regions that include multiple nation-states. Macro-regions are organizing into political and economic cooperatives. The Council of the Baltic Sea States, the Visegrad Group, the Weimar Triangle, and the Nordic Council are just a few of the examples of region-based cooperatives involved in advocating regional concerns and problems at the national, European, and international level. If Europe's regions are reorganizing and reinvigorating in such a way, then why couldn't regional powers rise and take on new responsibilities in the European Union?

My thesis will be divided into three chapters. The first chapter will examine the historical relationship of Poland and Belarus. Understanding not only the history of these two countries but a general history of Belarus is central to many of the issues that continue to affect contemporary political relations with Belarus and its neighbors. The analyzed relationship between Poland and Belarus will also provide the basis for the argument that Poland can be the bridge between the EU and Belarus, since Poland at numerous points throughout history has linked Eastern Europe with Western Europe. Moving into more recent history, the second chapter of my thesis will review and describe the current relationship between Belarus and Poland. The chapter will begin 
with the optimistic cooperation immediately following the collapse of the Soviet Union, then track and analyze the series of events contributing to Poland's deteriorating relationship with Belarus. At the time of this thesis, Poland-Belarus relations politically are strained, but Poland continues to support democratic development in Belarus. Seeing civil society as the key to social change and essential to a steady, mature democracy, Poland channels assistance to Belarus through the support of non-governmental organizations (NGOs), independent media, study visits, etc. The remainder of chapter two will describe these ventures and how effective they have been.

Since the second chapter will be dedicated strictly to Poland and Belarus, the third chapter will explore the European Union's relationship with Belarus. As mentioned, the European Union is looking to become more engaged in Eastern Europe, the Caucasus region, and Central Asia. While a brief overview of the previous programs will be included in this chapter, much of the analysis will be dedicated to the EU Neighbourhood Policy. For the purposes of the EU's relationship with the east, special attention will be given to the Eastern Partnership, a project which intends to nurture democratization and economic prosperity in the region as well as spread European standards and values to post-communist transition states across Eastern Europe and Eurasia. Because the focus of this thesis is Poland's role in bridging the east and the west, their contribution towards the Eastern Partnership and other initiatives will be highlighted. Following the third chapter will be the concluding remarks. After a synopsis of the findings, the thesis will finish with an overall assessment of Poland's role as a regional actor bridging the EU and Belarus. This part of the thesis will review what has worked, what has not worked, and how Poland, the EU, and others can learn from past experience in helping shape future programs in Belarus and perhaps even other states undergoing a similar transition.

As will be described in more detail in the first chapter, the Belarusian nation has been plagued by marginalization and persistent foreign influence throughout much of its existence. This has affected many facets of Belarusian identity, language being one of them. One of the vestiges of Soviet/ Russian domination over Belarus is that Belarusian as a language was persistently overshadowed by Russian. In a country where only eleven percent of the population is ethnically Russian, more than 60 percent of the population uses Russian as their primary language of communication; not even the current president of Belarus speaks Belarusian correctly. Because of the lack of legitimacy of Belarusian as a written and spoken language for so long, there exists a variation of spellings for many Belarusian names and places. The spelling 
inconsistencies are further exacerbated by the process of transliteration from Belarus, written in Cyrillic, to languages that use Roman characters. In fact, the differentiated spellings between Russian and Belarusian came about as a polite gesture by Poles to legitimize Belarus as a nationstate separate from Russia or other Slavic nations. Nevertheless, for an individual reading any literature about Belarus, the multiple spellings can be confusing and misleading. Using the example of the current Belarusian president, Aleksandr Lukashenko, his first name could be spelled Alexander, Aleksandr, Alyaksandr, or Aliaksandr, and his surname can be spelled Lukashenko, Lukashenka, or Łukaszenka. For the purposes of uniformity, in text this thesis will spell the president's name as it is spelled on official US government websites, Aleksandr Lukashenko. Other names and locations will be spelled in the way that they appear in the source. 


\section{CHAPTER 1: BETWEEN A ROCK AND A HARD PLACE Historical Dynamic of Poland and Belarus}

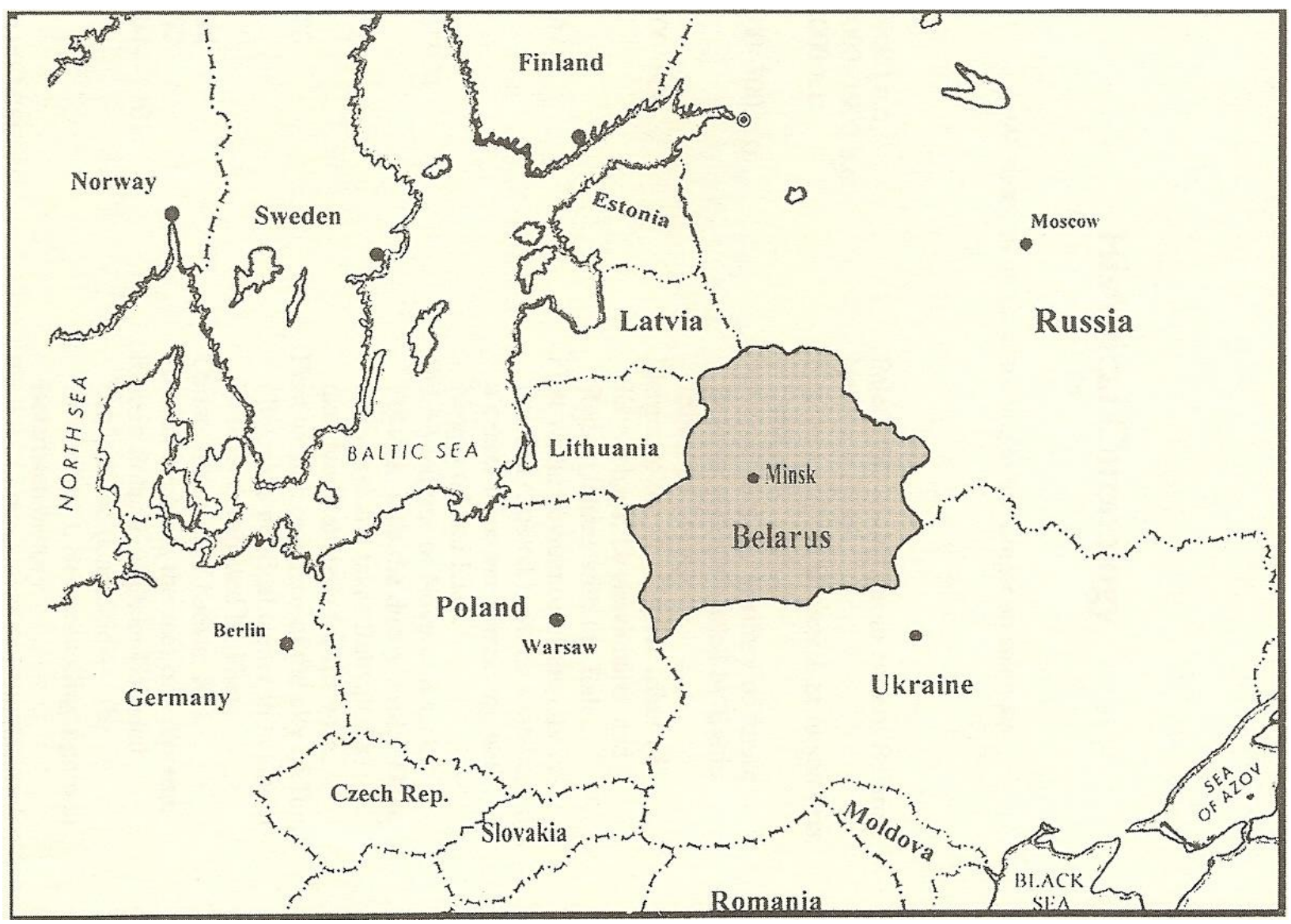

Source: Historical Dictionary of Belarus by Jan Zaprudnik

Poland and Belarus are neighboring countries situated in a region defined as Central and Eastern Europe. Over the centuries, this part of the world has been continually reshaped by war, conquest, and migration. Therefore, it is no surprise that these two countries share much more than just a $399 \mathrm{~km}$ border. ${ }^{1}$ Prominent Polish historical figures such as Tadeusz Kosciuszko were born in Belarusian lands. ${ }^{2}$ Also, substantial parts of modern-day Belarus were once under Polish rule. As a result, the concept of Belarus as a nation and as a state was heavily influenced by

\footnotetext{
${ }^{1}$ Jan Zaprudnik, Historical Dictionary of Belarus (Lanham: Scarecrow Press, 1998), 1.

${ }^{2}$ Andrew Savchenko, Belarus: A Perpetual Borderland (Leiden: Koninklijke, Brill NV, 2009), 37.
} 
Polish language, culture, and faith. Poland and Belarus have a deeply entrenched historical relationship, and in order to understand what will happen between these two countries, it is paramount to understand what has happened. For the purposes of this thesis, the role that Poland can play as a regional actor between Europe and Belarus can be more thoroughly understood given the precedent that Poland has set as Belarus's gateway to the west.

In the early history of Belarus, it is important to keep in mind the evolution of nationalism in Europe and how societies define people today compared to how those people defined themselves in the past. Our contemporary notion of what makes someone a "Pole" or a "Belarusian" is different from the middles ages when many other factors determined identity. Oftentimes, people preferred the more neutral appellation, "local." With a country that had no precedence of statehood such as Belarus, these monikers have important implications. To simplify the text of this chapter, contemporary titles for the ethnic groups involved will be employed and explanatory caveats will be added if necessary. Nevertheless, to fully comprehend what transpired during this period, it is crucial to let go of the current notion of nationality and approach these countries and the populations within them from a new (or rather, old) perspective.

Building upon literature by historians Timothy Snyder, Andrew Savchenko, and Jan Zaprudnik, the content of this chapter will be framed by the concept of Belarus as a "borderland" country. The borderland theory explains that Belarus and Belarusians have for centuries existed along the periphery of regional and global powers. Being located along this frontier has had a huge influence on the history and development of Belarus. More often than not, Belarusians' fate has been left to the decisions of outsiders, leaving them with little say or control over their destinies. The concept of a borderland is especially important in understanding the history of Belarus during the $19^{\text {th }}$ and $20^{\text {th }}$ centuries when this geopolitical borderland became the frontline of several devastating wars. It is also because of the position of Belarus as a borderland that the historical relationship with a third country, Russia, will be frequently discussed. A sufficient assessment of Belarusian history would be impossible without taking into account Russia. In fact, given the objective of this thesis, understanding Belarus-Russia history is just as important as understanding Belarus-Poland history. Belarus's history as a borderland country can be characterized by the idiom "between a rock and a hard place." Much like how Poland's history 
has been determined by being located between Russia and Germany, so has Belarus's history bared the brunt of being geopolitically sandwiched between Russia and Poland. ${ }^{3}$

\section{The Grand Duchy of Lithuania and the Polish-Lithuanian Commonwealth}

The Grand Duchy of Lithuania was a multiethnic, multi-confessional state in the medieval and early modern era of European history. At the height of its power, the Grand Duchy reached from the Baltic to the Black Sea and encompassed, in part or in whole, Lithuania, Latvia, Ukraine, Russia, and Belarus. ${ }^{4}$ In 1385, the Lithuanian Grand Duke Jagiello married the teenage queen of Poland, Jadwiga, at Krewa. The marriage between these two ruling families, known as the Krewa Union, brought together Poland and the Grand Duchy of Lithuania. The Krewa Union marks the first instance of Polish influence over early Belarusians. While significant in the history of Poland and Belarus, in the grand scheme the Union was merely a marriage that informally strengthened ties between two countries. Politically and economically, both Poland and Lithuania as states continued to function rather autonomously. As time went on, both internal and external factors prompted political actors to seek further integration and closer cooperation. Finally, in 1569, the Union of Lublin solidified Lithuania and Poland in a political and economic confederal state known as the Polish-Lithuanian Commonwealth. ${ }^{5}$

From the time of the Krewa Union to the partitions of Poland in the 1700s, Poland's influence and control over Belarusian culture was primarily exerted through religion and language. When Jagiello converted to Catholicism upon marrying Jadwiga, the Grand Duchy was effectively oriented towards the west. ${ }^{6}$ Since Catholicism was brought to the Grand Duchy by the marriage to a Polish queen, Poland became a conduit between the Vatican and Vilnius; "the introduction of Catholicism established a cultural link between Lithuania and Europe, and created the potential for Polish influence." ${ }^{77}$ Through willing and forced conversion, Belarusians were brought into the Catholic faith and thus under Polish influence. Linguistically, Polish surpassed all other tongues in the Commonwealth and became the language of politics and business. Slavonic, the linguistic precursor to Belarusian, facilitated the rise of Polish in the

\footnotetext{
${ }^{3}$ Savchenko, 3-5.

${ }^{4}$ Ibidem, 25.

${ }^{5}$ Timothy Snyder, Reconstruction of Nations: Poland, Ukraine, Lithuania, Belarus, 1569-1999 (New Haven: Yale University, 2003), 29.

${ }^{6}$ Jan Zaprudnik, Belarus at a Crossroads in History (Boulder: Westview, 1993), 21.

${ }^{7}$ Snyder, 18.
} 
Commonwealth because of the two languages' common Slavic roots. However, this prestige was short, and Slavonic was replaced by Polish as an official language in $1696 .{ }^{8}$ Not only was Polish a more effective language to use for the purposes of upward mobility within the country, but also Polish was the language through which philosophy, politics, and culture were being spread from the west to the east. ${ }^{9}$

The religious and linguistic divergence eventually evolved into a socio-economic hierarchy. The $15^{\text {th }}$ and $16^{\text {th }}$ centuries witnessed the rise of the Commonwealth gentry, or szlachta in Polish. In order to advance in the Polish-Lithuanian Commonwealth, noblemen had to adopt Polish language, customs, and culture. Polish was the language of the ruling class, while only the peasantry and country-folk spoke Belarusian. This "Polonization" amongst the gentry was very successful. Learning the Polish language became so ubiquitous that by the beginning of the Polish-Lithuanian Commonwealth, Polish was the de facto lingua franca of the Grand Duchy's elite; this trend was fashionable amongst Belarusian upper-class until World War I. ${ }^{10}$ This meant that ethnic Belarusians aspiring to be a part of the national elite became, be it voluntarily or reluctantly, Polish. In Minsk, the cultural hearth of Belarus, Poles made up 95\% of the gentry. ${ }^{11}$

This adoption of Polish culture by Belarusians was a particularly endemic phenomenon at the time. At a time when other nationalities in Europe were promoting and cultivating their indigenous languages and cultures, Belarusian high society was taking on one foreign culture in lieu of another. Throughout all the publications reviewed for this thesis, the lack of national consciousness amongst Belarusians, even compared to their Commonwealth compatriots, Ukrainians and Lithuanians, is widely agreed upon. While Polish language and culture enjoyed a period of dominance in this region at the time, throughout the rest of the continent the tide was turning against Poland. After several costly wars, Poland was dismantled in a series of partitions amongst Russia, Prussia, and Austria; by the beginning of the nineteenth century the state of Poland was no more. Lying east of the border, the region we know today as Belarus was entirely enveloped by the Russian Empire. ${ }^{12}$

\footnotetext{
${ }^{8}$ Zaprudnik, Historical Dictionary of Belarus, 38.

${ }^{9}$ Snyder, 20.

${ }^{10}$ Ibidem, 18-9, 55.

${ }^{11}$ Savchenko, 38.

${ }^{12}$ Zaprudnik, Belarus at a Crossroads, 40.
} 


\section{Legacies of Polish dominion during Russian rule in Belarus}

By the time of the partitions, a sizeable percentage of the peasant population of the former Polish-Lithuanian Commonwealth was ethnic Belarusian. ${ }^{13}$ Upper-class Belarusians were, at least linguistically and culturally, Polish, and the Belarusian peasantry adhered to a variation of Catholicism called Uniate that was created as an extension of Polish power. ${ }^{14}$ Like Polonization, the Russian Empire's newly acquired territory underwent Russification. Russia was determined to fully and effectively acculturate these lands that, according to their historical narrative, were theirs from the beginning. ${ }^{15}$ For Belarus, this meant quelling the influence of the Polish gentry. However, since the definition for being "Polish" was based on language and religion as much as anything else, the Polish-speaking Belarusian elite and Belarusian Catholics were persecuted during this time. ${ }^{16}$ Simultaneously, Russification was intent to extinguish an emerging Belarusian national identity. Symptomatic of the Enlightenment going on in Europe, small groups of Belarusians were struggling to assert "Belarusian" as a distinct and legitimate identity. From the top-down, the Russian Empire tried to squash Belarusian national identity through such measures as a ban on printing the Belarusian language in $1866 .{ }^{17}$ The policies of Russia aside, even within the Belarusian community aspirations for national development were complicated by a history inexorably linked to Poland.

Looking for a historical precedent for independence, Belarusian nationalists threw around notions of restoring the Grand Duchy of Lithuania. Their affinity for the Grand Duchy was primarily due to the elevated status of Belarusian (or more aptly, Slavonic) in the higher political echelon. However, proving this was difficult. Due to the Polonization of the Grand Duchy's political and cultural life, anything considered to be Belarusian about the Grand Duchy was long lost; "the people who sought to revive the Grand Duchy of Lithuania under the new name 'Belarus' were themselves constrained by their identification with an early modern Polishness.", 18 The Polish-Lithuanian Commonwealth experienced similar problems. Though the

\footnotetext{
${ }^{13}$ Aleksander Gieysztor et al., History of Poland (Warsaw: PWN, 1968), 344.

14 Ibidem, 45.

${ }^{15}$ Zaprudnik, Belarus at a Crossroads, 50.

${ }^{16}$ Piotr S. Wandycz, The Lands of Partitioned Poland, 1795-1918 (Seattle: University of Washington Press, 1974), 240-42.

${ }^{17}$ Ibidem, 244.

${ }^{18}$ Snyder, 41.
} 
Commonwealth once provided a proud historical state identity amongst various ethnic groups, any nostalgia was lost in the zeal and promise of modern nationalism. ${ }^{19}$

During the Belarusian national elites' struggle for legitimacy, their opinion of Poland began to sour. As Belarus's national movement began to gain momentum, Polish influence was perceived as more of a hindrance than a help. Though stewing for years, the distinctive split amongst ethnic groups of the former Polish-Lithuanian Commonwealth was highlighted by the January Uprising in 1863. Poles exploited nationalist sympathies to enlist Belarusian peasants to join them in a rebellion against the Russians. The Uprising failed, and many were disillusioned with Poles' artificial support for Belarusian nationalism. ${ }^{20}$ Some activists continued to cooperate with Poland, but many others branded Poland as a colonizer that retarded nation-building amongst Belarusians and had oppressed Belarus for centuries. ${ }^{21}$ Solidarity amongst ethnic groups of the former Commonwealth was gone, replaced with animosity and ethnocentrism.

\section{The $20^{\text {th }}$ Century}

Like many countries, Belarus was deeply affected by World War I. Being that it was located between the German and Russian empires, Belarus was the frontline for fighting and much bloodshed in 1915. ${ }^{22}$ Germans occupied large parts of Belarusian territory, including Minsk. Germans supported some aspects of Belarusian nationalism whenever it was to their benefit. As a result, segments of the Belarusian elite collaborated with the Germans: "Belarusian national elites, since their emergence [was] devoid of political power, [they] found that a modicum of influence could be attained from the occupation authority, which was prepared to be benevolent to the extent that Belarusian nation-building was deemed useful to Germany's national interests. ${ }^{23}$

The economic and human losses of World War I were tremendous. Nevertheless, it was during the last year of the war that the first Belarusian state emerged; "After signing the [Treaty of Brest-Litovsk], the executive committee of the previously dispersed Belorussian congress... proclaimed a Belorussian People's Republic on March 25. ${ }^{24}$ While the Germans were slightly

\footnotetext{
${ }^{19}$ Wandycz, XI.

${ }^{20}$ Snyder, 32.

${ }^{21}$ Savchenko, 76.

${ }^{22}$ Zaprudnik, Historical Dictionary of Belarus ,221.

${ }^{23}$ Savchenko, 69.

${ }^{24}$ Wandycz, 363.
} 
more inclined to support the advent of Belarusian nationalism than any other occupier, it was only from a perspective that would suit their interests. Therefore, Germany neither recognized this newly formed state nor facilitated in any way the actions of the BDR. ${ }^{25}$

The formation of an official state of Belarus is an event that is met with mixed feelings amongst Belarusians and historians. While it was an impressive feat that Belarus was declared a distinct political entity that historically had no equivalent, the politicking to make this dream of a Belarusian state a reality was largely happening at the highest political tier; the move to statehood had minor popular support emanating from the common Belarusian. ${ }^{26}$ Regardless, the Belarusian Democratic Republic was short-lived. No sooner was Belarus free from the Russian Empire is was once again incorporated into Russian dominion, only this time under the banner of the Soviet Union; “On December 20"th 1918 , the sixth regional conference of the Russian Communist Party (of Bolsheviks) in Smolensk converted into the First Congress of the Communist Party of Belarus and, on January 1, 1919, proclaimed the erection of the Belarusian Soviet Socialist Republic [BSSR]."27

By 1919, Belarus was once again turned into a battlefield. In the Polish-Soviet War, the Soviet Union rolled over Belarus towards Warsaw. Desperate for allies, Poles sought the support of Lithuanians and Ukrainians in the war against the Bolsheviks; Belarusians weren't engaged in the fight against the Russians to the extent of other eastern ethnic groups because their national character was significantly weaker than the others. ${ }^{28}$ Eventually the Poles pushed the Red Army back into the Soviet Union; in the Treaty of Riga that settled the war in 1921, territory containing Belarusians was divided between Poland and the Soviet Union. The Belarusian Soviet Republic continued to exist albeit with a small fraction of the world's Belarusians living in it. ${ }^{29}$

At this point, the experience of Belarusians differed depending on whether they lived in Poland or if they lived in Soviet Belarus. In Poland, life became particularly hard for Belarusians as they and other minorities were systematically persecuted and oppressed. ${ }^{30}$ Because of their legacy of peasantry, the ethnically Belarusian territory under control of Poland after the Treaty of

\footnotetext{
${ }^{25}$ Zaprudnik, Historical Dictionary of Belarus, 232.

${ }^{26}$ Savchenko, 72.

${ }^{27}$ Zaprudnik, Belarus at a Crossroads, 70.

${ }^{28}$ Richard M. Watt, Bitter Glory: Poland and its Fate 1918-1939 (New York: Simon and Schuster, 1979), 95-8, 180.

${ }^{29}$ Zaprudnik, Belarus at a Crossroads, 75.

${ }^{30}$ Martin Dean, Collaboration in the Holocaust: Crimes of the Local Police in Belorussia and Ukraine, 1941-1944
} (New York: St. Martin's Press, 2000), 2. 
Riga was poor, underdeveloped, and economically stagnant. ${ }^{31}$ Due to pressure from world powers at the end of World War I, Poland reluctantly agreed to a law respecting national minorities. However, very rarely did the government observe it: ${ }^{32}$

“By 1924 Polish authorities felt ready to start pressure on the 'Eastern Provinces,' trying to make them linguistically Polish by closing non-Polish schools, banning non-Polish publications, and settling Polish colonizers. Speeches by the [Belarusian] and Ukrainian deputies... catalog a long litany of complaints about abuses and atrocities at the hands of the authorities at all levels." 33

The situation only got worse as Poland took a turn toward authoritarian rule. By the late 1920s Poland grew disenchanted with its experiment in parliamentary democracy. ${ }^{34}$ Tensions continued to mount between left and right factions within the state. After several attempts at reconciliation, the chief military officer during the Polish-Soviet War and one of the architects of the revived Polish state, Marshal Jósef Piłsudski, staged a coup and attacked the sitting government on May 14, 1926. ${ }^{35}$ Initially, Belarusian political activists were supportive of the coup as they certainly did not have any sympathizers in the right-wing regime. Therefore, they backed Piłsudski but with an air of caution. ${ }^{36}$ Piłsudski was a federalist, so he envisioned a Poland ruled by Poles but containing semiautonomous communities inhabited by the country's various ethnic groups. His support for national minorities masked his ulterior motive to win over the hearts of ethnic minorities in the eastern borderlands so they would favor Poland over Russia. Once again though, nationalism was encouraged amongst Ukrainians and Lithuanians, not Belarusians. ${ }^{37}$ While Piłsudski was supportive of some aspects of Belarusian cultural development under federalism, he (along with most other Poles) was an expansionist at heart; for them, the eastern territory rightfully belonged to Poland. ${ }^{38}$ Officially, Belarusians were categorized as a "nonhistorical" ethnic group that had no claim to statehood. ${ }^{39}$ Any concessions towards Belarusians were lost in a frenzy of nationalistic politicians who were determined to

\footnotetext{
${ }^{31}$ Savchenko, 96.

${ }^{32}$ Watts, 329.

${ }^{33}$ Zaprudnik, Belarus at a Crossroads, 83.

34 Ibidem, 147.

${ }^{35}$ Andrzej Garlicki, Jósef Piłsudski, 1867-1935 (Hants: Scolar Press, 1995), 136.

${ }^{36}$ Antony Polonsky, Politics in Independent Poland 1921-1939 (Oxford: Clarendon, 1972), 175.

${ }^{37}$ Watt, 67-8, 93-4.

38 Ibidem, 93-4.

${ }^{39}$ Zaprudnik, Belarus at a Crossroads, 86.
} 
construct an ethnically homogenous Polish state. Military concerns frequently shaped the government's positions on minorities; at the time some feared that excessive rights and autonomy granted to minorities encouraged separatist ideas that would in turn weaken Poland strategically. ${ }^{40}$ Unfortunately, Piłsudski and his regime only made life harder for ethnic minorities in Poland. Once again, the problems at hand were language and, even more so, religion. The new constitution, approved in 1934, made it easier to restrict civil liberties and discriminate against faiths other than Catholicism. ${ }^{41}$ Many other social and cultural institutions were closed down for being affiliated with subversive groups or foreign enemies. As Belarusians were politically subdued, the Polish government also looked to disband non-Catholic denominations; Orthodox Belarusians were faced with the prospect of deportation if they did not convert to Catholicism. ${ }^{42}$

Because of the level of injustice against Belarusians in Poland, many ethnic Belarusians believed the situation was much better on the other side of the border in Soviet Belarus. A lack of information disseminating from the BSSR was probably to blame, but many saw the Soviets as nurturing Belarusian nationalism. ${ }^{43}$ Indeed, a certain level of progress was achieved, primarily because of the Soviet Union's two-faced approach to nationalism. Moscow permitted some semblance of national development so long as it stayed in line with party politics. For instance, schools in the BSSR taught in Belarusian, and literacy rates improved amongst the populace. ${ }^{44}$ However, in the BSSR it was not that Belarusian was promoted so much, but that Polish was downgraded. As the Polish-speaking gentry became the bourgeois enemy in the Soviet class warfare, the opportunity emerged for Belarusians to enter the ranks of national elite that for so long were occupied by Poles. ${ }^{45}$ Furthermore, in schools Poles were characterized as nefarious, and aspects of Polish culture (mostly, language and Catholicism) were severely restricted or banned. $^{46}$

Whatever small achievements that were made in Belarus under the Soviet Union were overshadowed by the terror and maltreatment that prevailed. In Soviet Belarus, many aspects

\footnotetext{
${ }^{40}$ Polonsky, 448.

${ }^{41}$ Zaprudnik, Belarus at a Crossroads, 87.

${ }^{42}$ Ibidem, 85.

${ }^{43}$ Savchenko, 10.

${ }^{44}$ Ibidem, 82.

${ }^{45}$ Ibidem, 92.

${ }^{46}$ Jan T. Gross, Revolutions from Abroad, The Soviet Conquest of Poland's Western Ukraine and Western Belorussia (Princeton: University Press, 1988), 126-8.
} 
Belarusian cultural development were ruthlessly oppressed. ${ }^{47}$ The Belarusian Soviet Socialist Republic continued to exist as a state, but it was far from independent. Moscow unabashedly directed its foreign policy and appointed government leaders. Belarus did not escape the ethnocide and politically-motivated killings that were common themes in the new Soviet republics at this time. Members of the national intelligentsia, writers, scientists, clergy, and activists were arrested and executed en masse throughout the 1930s; others fled or committed suicide. In Kurapaty, a forest outside of Minsk, more than 100,000 Belarusians were systematically killed over four years before and after the start of World War II. ${ }^{48}$ The Belarusian experience was hard in the interwar Polish Republic. However, nothing happening in Poland could compare to the mass murder and violence that occurred just over the border. The 1930s were a grim decade for the Belarusian people, and with World War II looming in the distance, the worst was yet to come.

Poland and Belarus suffered terribly during World War II. Some ethnic minorities in interwar Poland welcomed the invasion of the USSR in 1939 because they were still under the delusion that the Soviets would be better than Poles; Belarusians in particular favored the Soviets because of their affinity for communism. In the absence of law and order immediately following the Soviet invasion of Poland, there were a number of documented attacks between Poles and Belarusians. However, evidence suggests that these were sporadic and predominantly based on avenging personal grudges rather than a massive uprising against Poles. ${ }^{49}$ Despite the hostility between Poles and Belarusians, their respective experiences in World War II were rather similar in terms of incalculable destruction and unimaginable level of death. Both countries lost huge percentages of their population, roughly $16 \%$ in Poland and around $20 \%$ in Belarus. ${ }^{50}$ The Jewish populations of each country, the largest in Europe, were almost completely exterminated. Their capital cities, Warsaw in Poland and Minsk in Belarus, were leveled. Belarus and Poland were also home to many of the most notorious death camps where millions of Europeans perished because of starvation, disease, shootings, and gas. Partisan activity was very high in Poland and especially in Belarus, where the physical geography of thick forests and treacherous marshes was

\footnotetext{
${ }^{47}$ Savchenko, 77.

${ }^{48}$ Zaprudnik, Belarus at a Crossroads, 87.

${ }^{49}$ Gross, 31-35.

50 Timothy Snyder, Bloodlands: Europe Between Hitler and Stalin (New York: Basic Books, 2010), 404, AND Tadeusz Piotrowski, Poland's Holocaust: Ethnic Strife, Collaboration with Occupying Forces and Genocide in the Second Republic, 1918-1947 (Jefferson: McFarland \& Company, 1998), 305.
} 
ideal for hiding. While these groups were often very scattered, unorganized, and fighting for differing causes, they added an additional layer of terror that the Belarusian and Polish people had to endure. The variety of suffering was great, and both Poland and Belarus suffered tremendously.

At the end of World War II the border between Poland and Belarus was once again redrawn. Initially further to the east, the new boundary was along the "Curzon line" that delineated Poland and Belarus before the Russo-Polish War. The symbolism of the border between the two countries being named by a foreign official (in this case a British foreign minister) is worth noting. With territorial restructuring came resettlement. The majority of the migration was headed westward out of Belarus and into Poland. Some of these people, particularly ethnic Poles and Catholic Belarusians, were escaping the Soviets. Many others were deported by force in order to make the ethnic profile of the region predominantly Belarusian: ${ }^{51}$ "By 1947, when the crest of the exodus had passed, a total of 120,000 Poles, 85,000 Jews, and 469,000 Belarusans had resettled from Belarusan territories to the west of the Curzon line. ${ }^{, 52}$ The Polish government tried to remove hundreds of thousands of Belarusians from Polish territory, but it was not successful.

For the remainder of the $20^{\text {th }}$ century until the collapse of the Soviet Union, PolishBelarusian relations came to a standstill. The highly centralized nature of the USSR meant that contact between Soviet republics and other countries happened through Moscow. For Belarus, the rule of the Soviet Union was accompanied by heavy denationalization and Sovietization efforts. Maintaining the narrative that dated back to the Bolsheviks, Soviet authorities fudged history in order to sever Belarus's historical ties with Poland and emphasize Belarus as a part of Russia. Politically, relations between these two countries were extremely difficult given the hegemony of the Soviet Union. Nevertheless, this did not mean that Poles completely forgot about the plight of Belarusians. Throughout the Cold War, Polish intellectuals and political activists advocated for reconciliation with Poland's eastern neighbors and expressed a sincere sense of solidarity for national independence for the countries of Belarus, Ukraine, and

\footnotetext{
${ }^{51}$ Savchenko, 8.

${ }^{52}$ Zaprudnik, Belarus at a Crossroads, 102.
} 
Lithuania. ${ }^{53}$ With the demise of Communism in the 1980s and 1990s, relations between Poland and Belarus entered a new chapter.

\section{Conclusions}

The shared history of Poland and Belarus goes back hundreds of years. The Grand Duchy of Lithuania and, later, the Polish-Lithuanian Commonwealth gradually introduced Polish language, customs, political traditions, and religion into Belarusian society. As a result of this acculturation, the upper class of Belarus was effectively dominated by its ties to Poland from the middle ages to the $20^{\text {th }}$ century. The modern historical relationship was characterized by Poland and Russia each vying for influence and control of the country, neither seeing Belarus as a nation fit for a state. ${ }^{54}$ Enmity between Poles and Belarusians was palpable during the interwar years when Polish statehood resulted in the oppression of minorities. Warsaw's approach to Belarusians and all national minorities within Poland was a leading cause for the demise of a truly democratic Polish Republic. ${ }^{55}$ Following World War II, diplomatic relations between Poland and Belarus were dominated by the Soviet Union. For Belarus, the process of Sovietization that was paused because of the Second World War resumed, and the country endured decades more of denationalization. ${ }^{56}$

There is a general consensus amongst scholars and political scientists that Belarus's persistent existence in the borderlands of powerful nations has hampered the democratic consolidation of the country. Furthermore, the absence of (non-Polish) national elites, the relative economic success under the Soviet Union, and the legacy of passivity amongst the Belarusian populace have all contributed to making Belarus the last dictatorship in Europe. For Belarusians, there was always someone calling the shots, be it a Pole, a Russian, or now, President Lukashenko.

For much of history, a connection with Poland has resulted in more exposure to developments going on in Western Europe. In the most recent memory of modern-day Belarusians and their descendents, Poland's behavior in western Belarus lingers. Though this is a

\footnotetext{
${ }^{53}$ Stephen R. Burant, "International Relations in a Regional Context: Poland and Its Eastern Neighbours - Lithuania, Belarus, Ukraine," Europe-Asia Studies 45 (1993): 395-400.

${ }^{54}$ Watt, 92.

${ }^{55}$ Ibidem, 459.

${ }^{56}$ Zaprudnik, Belarus at a Crossroads, 107.
} 
factor Poland will have to overcome in forging strong relations with Belarus today, the extent to which history will affect the decision-making process (in a democratic Belarus) is uncertain; previous regional dynamics could have an impact on several different directions in terms of future cooperation and assistance. For instance, the antagonistic relationship and legacy of oppression in the twentieth century might lead one to believe that Poland would be the last country Belarus would see as a trustworthy partner. However, if this is the case, then why would Belarus sustain its strong links to Russia, a country whose presence in the country was more recent and arguably more detrimental?

The history of Poland and Belarus has run a relatively parallel course for centuries. However, as will be further developed in the next chapter, the collapse of Communism and the fall of the USSR led to a divergence in Polish and Belarusian history. Political activism in Poland was one of the most important factors in bringing down Communism in Eastern Europe. As a result, Poland actively oriented its policy westward, embracing a free market economy and joining NATO and the EU. Belarus, on the other hand, languished and held onto many remnants of its Soviet past. With the world system changing so drastically over twenty years, what role will Poland play in the future of Belarus? 


\section{CHAPTER 2: EXPORTING EXPERIENCE \\ Polish-Belarusian Relations since the Collapse of Communism}

Building upon the history between the two countries, this chapter will review Poland's relationship with Belarus from 1991 to the present. Initially, diplomatic relations between the two countries after independence were rather positive and gave many a reason for optimism. However, the situation deteriorated around 1994 when Belarus's current leader, Aleksandr Lukashenko, was elected. While Poland continued to strengthen ties to Europe, striving for a liberal western-style democracy, Lukashenko's policies maintained Belarus's strong bond to Russia as well as fortified his power in a Soviet-style manner. With Poland's accession to EuroAtlantic institutions, the divide between the two countries has only grown deeper. Reflecting the interwar years, the minority issue has frequently been a point of contention between the two countries. Despite the quarrels taking place between Minsk and Warsaw, Belarus is still a priority country for Polish assistance and in the foreign policy considerations of the Polish government. The last portion of this chapter will explore various methods by which Poland is pursuing its interests in the country, outside of interacting with Lukashenko, via independent media outlets, non-governmental organizations, and other instruments of assistance.

\section{The Immediate Post-Soviet Cooperation}

As the USSR began to disintegrate, Poland was one of the states on the forefront in encouraging Soviet republics to pursue independence. During this period, Poland had to address the dramatic changes occurring in the Soviet Union delicately, as the outcome was unclear. Therefore, Poland's political approach to the individual republics of the Soviet Union was characterized as a "two-track" policy. Poland carefully initiated bilateral relations with the neighboring Soviet states, Lithuania, Belarus, and Ukraine, without renouncing the existing agreements and dialogue with the Soviet Union. ${ }^{1}$

In Belarus, Poland's first attempt at bilateral relations was unsuccessful. In 1990, a diplomatic mission from Warsaw was sent to Minsk to begin what many hoped to be the first step in a new stage of Polish-Belarusian relations, one marked with mutually beneficial political,

\footnotetext{
${ }^{1}$ Burant, “International Relations in a Regional Context," 405.
} 
economic, and social development. However, issues surrounding minority populations in both countries as well as the border between Poland and Belarus proved to be irreconcilable and negotiations were brought to a standstill. ${ }^{2}$ Based on my research, this first failure at establishing relations between the two countries was due to two primary factors working against Poland in Belarus. First of all, unlike other republics at the time that were eager to break any and all political ties to the Soviet Union, Belarus was relatively passive about gaining independence. Belarusian officials were timid about stepping out on their own and instead continued to look to Moscow for guidance. The perceived unwillingness for Belarusian politicians to disavow themselves from the Soviet Union complicated the diplomatic interaction between Poland and Belarus and aggravated Polish officials. In addition, Poland's maltreatment of ethnic Belarusians during the interwar years was another obstacle to overcome. The national memory of Belarus negatively stereotyped Poles as aggressors from their behavior in western Belarus. This was evident when Krzysztof Skubiszewski, the Polish Minister of Foreign Affairs from 1989 to 1993, visited Minsk for the first time and was met with protesters decrying Poland for injustices against Belarusians during the time of the Second Republic. ${ }^{3}$

Due to this first disappointment in 1990, Poland was left with little time to construct stable diplomatic relations with Belarus prior to its independence. However, the variables that would lead to the demise of the USSR were already set in motion. Before long, the Soviet Union folded, and on September 3, 1991, Poland recognized Belarus as an independent and sovereign state. ${ }^{4}$ Despite the initial setback, the next couple of years were marked with a number of positive gains in cooperation between the neighboring countries. Not long after independence, Belarus concluded the Treaty on Good-Neighbourly Relations and Friendly Cooperation as well as an economic agreement with Poland. Because of this as well as Poland's more fluid access to the Euro market, trade between Belarus and Poland increased by 20 percent. ${ }^{5}$ To facilitate international trade, Poland permitted the export of Belarusian products out of the Polish port city

\footnotetext{
${ }^{2}$ Ibidem, 406.

${ }^{3}$ Agnieszka Magdziak-Miszewska, "Belarus: Poland's Strange Neighbor," in Independent Belarus: Domestic Determinants, Regional Dynamics, and Implications for the West, ed. Margarita M. Balmaceda, James I. Clem, and Lisbeth L. Tarlow (Cambridge: Harvard University Press, 2002), 346.

${ }^{4}$ Zaprudnik, Belarus at a Crossroads, 244.

${ }^{5}$ Burant, "International Relations in a Regional Context," 407.
} 
of Gdynia. ${ }^{6}$ Trade between Poland and Belarus was approximately 306 million USD in 1992 , making Poland Belarus's primary non-CIS trading partner in the world. ${ }^{7}$ Within the third sector, the early 90s was a golden age of Belarusian civil society. NGOs, associations, and clubs appeared by the thousands as Belarus awoke from decades of Soviet civil dormancy. Many Belarusians NGOs and non-profits looked to Poland as a role model, since its civil society was one of the most developed in Central and Eastern Europe. ${ }^{8}$

At the local level, the "bazaar" culture between Poland, Belarus, and Ukraine also flourished. With the fall of the Soviet Union and the relaxed borders, Belarusians and others from neighboring states would traverse the borders daily selling their products to consumers in Poland, as Poles were generally on better economic footing than their Ukrainian or Belarusian counterparts. It is difficult to attach a concrete value to this informal level of trade but the economic benefits of it were evident. Trans-border trade provided many individuals with capital they had never had before. This capital was invested into businesses and was also spent in the area, benefitting others who were not directly participating in the bazaar culture. From this increase in revenue and entrepreneurship emerged a new middle-class on both sides of the border. These rudimentary trade networks evolved into the more formal transnational trade hubs, as many wholesale shops and firms were established along the border. This daily interaction was also a step in creating positive bonds and friendships between Poles and their eastern neighbors.

Why did this partnership decline? Poland's efforts in not just Belarus but Eastern Europe in general slowed down considerably after 1993 for a number of reasons. Firstly, the global powers at the time were intent to engage the Russian Federation and establish friendly relations with Boris Yeltsin to the extent that they looked the other way when it came to Russia's continued influence in Eastern Europe. Poland, eager to prove that it was more western than eastern, sided with the United States and others and backed off from its activity in the former USSR. ${ }^{9}$ In Belarus specifically, the 1994 election of Aleksandr Lukashenko, a roguish character with staunchly pro-Russian views, made Poland reconsider its support for the Belarusian government.

\footnotetext{
${ }^{6}$ Stephen R. Burant, "Poland's eastern policy, 1990-95," Problems of Post-Communism 48 (1996), Academic Search Complete, EBSCOhost (accessed September 20, 2011)."

${ }^{7}$ Magdziak-Miszewska, 360-61.

${ }^{8}$ Vaclau Areshka, "Non-Governmental Sector in Belarus: Traditions and Perspectives," in A Report of the Condition of NGOs and Independent Culture in Belarus, ed. Paweł Laufer (Lublin, Studio Format, 2011), accessed October 17, 2011, http://kulturaenter.pl/pliki/pdf-e/index.html,168-69.

${ }^{9}$ Stephen R. Burant, "Poland's eastern policy, 1990-95."
} 
Despite the promise of the early 90s, the progress Poland was making in Belarus fallowed and relations between the two countries subsided.

\section{The Rise of Lukashenko and the decline of progress in Poland-Belarus relations}

In any movement towards democratic consolidation, political scientists characterize countries as being "transition winners" and "transition losers," based on their success in achieving the tenants of a modern democracy (market economy, political pluralism, flourishing civil society, etc). In the wave of democracy that swept over the former Soviet Union, Central European states and the Baltic countries are proclaimed to be transition winners, while other countries in Eastern Europe, the Caucasus region, and Central Asia are deemed transition losers. In this dichotomy, Belarus falls into the latter category.

Despite the overall harshness of Soviet rule, Belarus was one of the better fairing and more developed of the Soviet republics. ${ }^{10}$ However, the transition to democracy was arduous, and many Belarusians found the living conditions to be considerably worse in their newly independent state than as a Soviet republic. Inflation was outrageously high, product shortages were commonplace, and corruption was rampant. ${ }^{11}$ Not unlike many other former Soviet states at the time, the Belarusian leadership changed very little. What was supposed to be a new government was instead a revamped nomenklatura with many of the same political figures holding the same positions (and profiting considerably under the so-called "market economy"), only this time under the guise of democracy rather than socialist dictatorship. ${ }^{12}$ The exception to this rule was Chairman of the Supreme Soviet Stanislaŭ Shushkevich, a physics professor and prominent figure in the politically-active and upwardly mobile Belarusian elite. However, his term was largely ineffective because Prime Minister Viacheslaŭ Kebich, a notorious lackey for Moscow during the Soviet era, wielded most of the power. ${ }^{13}$ The Belarusian electorate blamed the slow and difficult period of transition on the ineptitude of the crooked powers that be, and in the 1994 election they desired a leader who was a departure of the current regime, a paladin of the transition losers.

\footnotetext{
10 "Lukashenka at Bay," The Economist, December 12, 2010, 65.

${ }^{11}$ Leonid Zlotnikow, "Possibilities for the Development of a Private Economic Sector and a Middle Class as a Source of Political Change in Belarus" Independent Belarus, 125.

12 Rainer Lindner, "The Lukashenka Phenomenon" Independent Belarus, 79-80.

${ }^{13}$ David Marples, “Outpost of Tyranny? The failure of democratization in Belarus," Democratization 16 (2009): 757.
} 
Aleksandr Lukashenko was just that leader. A former KGB officer, teacher, and collective farms chairman, Lukashenko effectively capitalized on his position of being affiliated neither with the Belarusian intelligentsia nor Shushkevich's government. Rhetorically gifted and physically impressive, Lukashenko's maverick persona epitomized the everyman who would fight for the masses against a corrupt, illiberal regime. Lukashenko's campaign strategy tactfully blended populist resentment towards the sitting government while simultaneously evoking nostalgia for life as a part of the Soviet Union. In fact, while many countries in the region were trying vehemently to distance themselves from Russia, Lukashenko's platform was based on maintaining and strengthening Belarus's relationship with its neighbor to the east. ${ }^{14}$

When Lukashenko came to power, he did exactly this. For the rest of the 1990s Lukashenko's unabashedly pro-Russia policies pursued integration with Russia economically, politically, and militarily. In addition to the 1992 Free Trade Agreement that was concluded prior to his presidency, Lukashenko immediately started negotiating with Yeltsin such measures as a shared currency, a customs union, and cooperation on defense and border patrol. In addition, through a number of referenda Lukashenko reintroduced Soviet-era symbols along with Russian language and culture. In 1999, the Russian Duma gave overwhelming support to a treaty that would merge the two countries into a confederate state. In essence, after not even a decade of independence, the re-integration of Belarus into Russia became a question of not "if" but "when." 15

This fixation on Russia prompted Poland to tread lightly in continued cooperation with the Lukashenko regime. With the memory of the Soviet Union still fresh, Poland was suspicious of Russia attempting to establish a network of subservient states on the western borderlands which had the potential to be a threat to Poland's independence. ${ }^{16}$ Likewise, Lukashenko (and Yelstin) saw Poland's new membership in NATO as an incursion of western military influence into Eastern Europe. Poland was not only cautious of Lukashenko's affinity for Russia in his foreign policy, but also his domestic authoritarian leadership style. A referendum pushed through in 1996 abolished the existing constitution and consolidated power in the executive, as well as

\footnotetext{
${ }^{14}$ Timothy J. Colton, "Belarusian Public Opinion and the Union with Russia" Independent Belarus, 23.

${ }^{15}$ David Marples, "Is the Russia-Belarus Union Obsolete?," Problems of Post-Communism 55 (2008): 25-27.

${ }^{16}$ Burant, "Poland's Eastern Policy, 1990-95."
} 
loaded the national government with rubber stamps for Lukashenko. Political opposition was subordinated, private enterprise was quelled, and civil society was hollowed. ${ }^{17}$

The flagrantly undemocratic conduct of Lukashenko was met with acute condemnation by the European Community. From the very beginning, Poland was one of the most outspoken critics of the Lukashenko regime, and called attention internationally to Belarus's regression into authoritarianism. Tensions peaked in the summer of 1998 when Belarusian authorities evicted Western diplomats from their residences in the Drozdy district of Minsk. In response to the blatant disregard for the Vienna Convention and international protocol, the European Community banned Lukashenko and many members of his government from entering Member States' territory. Poland, however, did not recognize the ban extending to Poland. Foreign Minister Bronisław Geremek pointed out that Poland has a unique position in relations to Belarus compared to other European states (read: a border country containing a Polish national minority); ostracizing the Belarusian government would only encourage Lukashenko's hard-line rule and could have detrimental effects on the population of Belarus and particularly Belarusian Poles. This decision was met with reserved acquiescence by Brussels, and satisfaction by Belarusian authorities. ${ }^{18}$

In this author's opinion, Poland's strategy towards Belarus at this period was ill-conceived. As mentioned, Poland was a persistent advocate in Europe for the importance of nurturing democratic principles in Belarus. Yet when the European Community finally took concrete action against Lukashenko, Poland protested. Poland's reasons for doing so were supposedly on behalf of the struggling opposition movement in Belarus, but even factions within the opposition wanted Poland to be firmer with Lukashenko. Polish officials also cited the Polish minority in Belarus as a reason not to break off communication with Belarus. However, it was exactly because of the Polish minority in Belarus that Poland should have been the most enthusiastic at weakening Lukashenko before he became entrenched in power. Moreover, at the time of the Drozdy affair, Poland was chairing the Organization for Security and Co-operation in Europe (OSCE). The clout that came with this position meant that Poland's opinion would have carried

\footnotetext{
${ }^{17}$ Lindner, 87-92.

18 Jacek Lepiarz, "Poland wants to be the bridge between the E.U. and Belarus," Deutsche PresseAgentur, date accessed October 6, 2011, http://www.lexisnexis.com.www.libproxy.wvu.edu/hottopics/Inacademic.
} 
considerable weight within the international community. Like 1993, 1998 was another year of lost opportunity for fortifying Belarus's democracy.

Even though 1998 was a failed year in the democratization, it marked an important shift in Poland's relationship with Belarus. Shortly thereafter Poland acceded to NATO (1999) and the European Union (2004). This pro-western direction exacerbated the discordance between Poland and Belarus. In terms of bilateral relations, as Lukashenko proved himself to be more incorrigible and headstrong, Poland recognized that any progress through state-to-state relations was rather unlikely. Instead, Poland began to channel its efforts into grassroots support for the Belarusian population, particularly independent media and non-governmental organizations. From then on, empowering civil society and reaching out to the Belarusian population was the objective of Poland's Belarus policy. As for the relationship between Lukashenko and the Polish government, it followed a rather predictable waltz: Lukashenko became more and more dictatorial, and Poland would censure him for his conduct but no action would come of it. This war of words never amounted to much action on either side. However, tensions boiled over in 2005 when Lukashenko's iron fist came down on the Polish minority in Belarus.

\section{Issues of the Polish Minority in Belarus}

As stated before, Poland and Belarus both house minority populations of the other in their territory. In Belarus, roughly 4 percent of the population is ethnically Polish, and in Poland 0.1 percent of the population is Belarusian. ${ }^{19}$ The status of these minority populations has frequently been critical to relations between Belarus and Poland. Particularly in the past few years, harassment by Belarusian authorities of Polish minority organizations has been instrumental in shaping Polish foreign policy towards Belarus and Lukashenko.

The most notorious crisis involved one of the more active ethnic Polish organizations in Belarus, Zwiazek Polaków na Biatorusi (ZPB) or the Union of Poles in Belarus. ZPB has been around since the late 1980s and strives to represent Polish interests in Belarus; "The [ZPB's] main thrust is to conserve Polish culture and promote Polish education in Belarus. ${ }^{20}$ Despite the troubled recent history of Polish-Belarusian relations, ZPB operated cogently by complying with

\footnotetext{
19 "CIA World Factbook," last modified November 15, 2011, https://www.cia.gov/library/publications/the-worldfactbook/index.html.

${ }^{20}$ Alexandr Pilestsky, "The Belarusian-Polish Struggle," New Presence: The Prague Journal of Central European Affairs 12 (2010): 60.
} 
Belarusian authorities. However, this changed in 2005 when the organization held an election for president and the preferred candidate of the Belarusian government, Tadeusz Kruchkowski, lost to Andżelika Borys. Belarusian authorities intervened and refused to recognize the election as valid. Members of ZPB countered that Belarusian authorities had tampered with the election, and this violated both Belarusian law as well as the Treaty on Good-Neighbourly Relations and Friendly Cooperation between Poland and Belarus. ${ }^{21}$ Incensed, Belarusian authorities detained Borys along with many of her supporters. The Polish government was enraged by this act of injustice and no longer recognized the Belarusian-sanctioned ZPB. Lukashenko, convinced that Poland and other foreign elements were collaborating with minorities to overthrow him, arrested Polish journalists and harassed Borys and her constituents. ${ }^{22}$ Poland and Belarus expelled a number of diplomats from their respective countries, and Poland threatened to withdraw its embassy. ${ }^{23}$

In 2010, another dispute arose between the Polish minority and the Belarusian government. Teresa Sobol, leader of the Polish House in the town of Ivanets, west of Minsk, was active in the Polish community there and worked with Borys's "unofficial" ZPB. That year, Sobol was accused of misappropriation of funds and taken to court. Undeterred by this clear attempt at intimidation by the government, Sobol continued to work as the head of the Polish House. The Belarusian government called for the election of a new leader. Sobol was re-elected, not to the liking of the Belarusian government; "within a week of Sobol's electoral victory, the Polish House was cordoned off with an official court seal... Teresa Sobol was expelled from the organization and was restricted from entering the Polish House. ${ }^{24}$ This local dispute soon grew to a transnational conflict. The Polish Ministry of Foreign Affairs quickly condemned Belarus's oppression of the Polish minority. Poland threatened Lukashenko with not only retribution from Poland but also European institutions.

Lukashenko's response to the Ivanets conflict changed depending on whom he was addressing. Playing a game of semantics, Lukashenko denied there was even an issue of the

\footnotetext{
21 “O Nas," last modified 2010, http://zpb.org.pl/node/1.

22 "Belarus/ Poland: Harassment of Polish journalists and media continues," last modified October 28, 2005, http://arabia.reporters-sans-frontieres.org/article.php3?id article=15452.

${ }^{23}$ C.J. Chivers, "Europe: Polish-Belarussian Tensions Increase," The New York Times, July 28, 2005, date accessed October 6, 2011, http://query.nytimes.com/gst/fullpage.html?res=9D00E4D9103FF93BA15754C0A9639C8B63.

${ }^{24}$ Piletsky, 62.
} 
Polish minority in Belarus as the concept of a "national minority" didn't exist in Belarus. ${ }^{25}$ However, when Lukashenko met Foreign Minister Sikorski in Ukraine a few months after the dispute, the two agreed to establish a bipartisan committee to review the legal action taken against Borys and her supporters. This initiative lost momentum after the death of Polish Deputy Minister of Foreign Affairs, Andrzej Kremer, in the Smolensk plane crash. ${ }^{26}$ In the end, Lukashenko backed off from open persecution of the Polish minority, at least enough to assuage the Polish government. ${ }^{27}$ His placatory performance was intended to convince the European Union he was willing to play by its rules. The Union was starting to re-engage Belarus, and since there was a lot of money riding on the EU's seal of approval, Lukashenko couldn't afford the bad publicity. The 2010 presidential election, however, provided Lukashenko with enough bad publicity for years to come.

\section{The 2010 Belarusian Presidential "Elections"}

The outcome of the 2010 elections in Belarus was going to be crucial for the next step in Belarus's external relationship with Poland, the EU, and others. Whether or not the elections were deemed free and fair by international standards was paramount. In an interview with the Polish newspaper Rzeczpospolita, Lukashenko balked at the ultimata delivered to him from abroad. He noted, with an air of condescension, that elections in Belarus would be fair like they always have been. At the same time, he stated confidently, "I will stay on as long as I want."28

The presidential elections were held on December 19, but the conduct and outcome were anything but legitimate. Including Lukashenko, there were ten candidates on the ballot. From the opposition, the men who had the most support were Uladzimir Nyaklayeu from the Speak the Truth Campaign (16\%) and Andrey Sannikau from the For a European Belarus party (10\%). Lukashenko was predicted to achieve between $30-40$ percent of the popular vote. While to some

\footnotetext{
25 "Belarusian leader rejects accusations of crackdown on Polish minority," BBC Monitoring Kiev Unit Supplied by BBC Worldwide Monitoring, May 23, 2010, date accessed October 6, 2011, http://www.lexisnexis.com.www.libproxy.wvu.edu/hottopics/Inacademic.

26 "Belarusian foreign minister interviewed on relations with EU, Polish minority," BBC Monitoring Europe Political Supplied by BBC Worldwide Monitoring. May 26, 2010, date accessed October 6, 2011, http://www.lexisnexis.com.www.libproxy.wvu.edu/hottopics/Inacademic.

27 "Polish minister to push for uniform EU visa policy for all eastern neighbours," BBC Monitoring Europe Political Supplied by BBC Worldwide Monitoring, May 11, 2010, date accessed October 6, 2011, http://www.lexisnexis.com.www.libproxy.wvu.edu/hottopics/Inacademic.

28 "Belarusian leader interviewed on coming election, ties with Poland, Russia," BBC Monitoring Europe Political Supplied by BBC Worldwide Monitoring, November 10, 2010, date accessed October 6, 2011, http://www. lexisnexis.com.www.libproxy.wvu.edu/hottopics/Inacademic.
} 
this might be a surprisingly high number for an autocrat, it was half the number of Lukashenko's "official" estimate, and would not give the president the $50 \%$ threshold he needed to win without holding a run-off election. On the night of the election, the opposition candidates planned a demonstration on October Square in Minsk as a display of solidarity. To deter the event, the Belarusian government converted October Square into a skating rink and warned that anyone present for anything other than skating would be subject to arrest. ${ }^{29}$ The demonstration took place that evening, but due to the hindrances put in place by government authorities it was decided to move it to Independence Square, home of the parliament building and the Central Electoral Committee.

At this point, the situation began to unravel. Riot police surged onto the crowds at Independence Square, arresting hundreds of protesters and beating thousands more. Nyaklayeu did not even make it to the first demonstration at October Square; while en route he was stopped by traffic police and beaten so severely he had to be taken to the hospital. While at the hospital security forces abducted him and no one, not even his wife, heard from him for more than a week. ${ }^{30}$ Sannikau also sustained serious injuries and was imprisoned with seven other opposition candidates, all facing prosecution. Adding to this orgy of repression, the leader of the Union Civic Party, Anatol Lyabedzka, was detained and the offices of several organizations and businesses such as European Radio for Belarus were raided. ${ }^{31}$ In the end, the orchestrator of this violence, Aleksandr Lukashenko, was declared the winner of the election with a laughable $80 \%$ of the popular vote. ${ }^{32}$

In the wake of the election, there was a litany of condemnations coming in from around the world. Scornfully, the European Union was prepared to swiftly put in place a new round of sanctions. Yet again Poland disagreed with the EU's plan of action. While Sikorski stated publicly that forms of assistance such as loans from the EU, IMF, the World Bank, and others should terminate, he emphasized the detrimental effects of ostracizing Belarus. According to Sikorski, totally isolating Belarus from the international community would help neither Poland's interest nor the interests of those residing in Belarus. Therefore, any punishment towards Belarus should involve targeting the Lukashenko administration and those entities which are supporting

\footnotetext{
${ }^{29}$ Uladzimir M. Padhol and David R. Marples, "The 2010 Presidential Election in Belarus," Problems of PostCommunism 58 (2011): 9-11.

30 Jay Nordlinger, "Belarus Assaulted," National Review 63 (2011): 24.

${ }^{31}$ Padhol and Marples, 16-17.

${ }^{32}$ Nordlinger, 26.
} 
his dictatorship while trying to spare the effects from harming the Belarusian population. It is because of this that Poland decided not to abandon current projects with Belarus, such as a border traffic agreement that would ease interstate migration for citizens within the border zones of the two countries. ${ }^{33}$

Poland continues its quasi-relationship with the Belarusian people by circumventing the government. In 2011 the Polish government waived visa fees for Belarusians, provided aid and asylum to victims of Lukashenko's harsh rule, and promised to double the allotted assistance to Belarusian groups supporting civil society. ${ }^{34}$ In February, the Polish government and others raised $€ 87$ million to help Belarusian independent media and civil society. ${ }^{35}$ The 2010 election once again proved that dialogue with Lukashenko is futile, but that his impropriety and tyranny would not bring down the entire country. Poland's aid to Belarus is the highest it has ever been, and it is channeled to organizations and individuals that are fighting for a free and democratic Belarusian state.

\section{Polish Foreign Aid to Belarus}

A recipient of aid from western powers during its own transition, Poland is now "paying it forward" to less-fortunate countries, especially in Eastern Europe. Financial support from abroad was critical to Poland's transition to a free-market democracy in the 1990s. ${ }^{36}$ In Eastern Europe, assistance has both a practical and ethical role. A prosperous and economically viable Belarus and Ukraine would provide stability for the entire region, something clearly in Poland's national interest. On a more altruistic level, Poland has expressed solidarity with its eastern neighbors, and feels a sense of obligation to help them in their transition. By donating and supporting countries' struggle for democracy and development, the country is more credible as a legitimate promoter of democratic principles in the world.

\footnotetext{
33 "Poland not to drop border traffic agreement with Belarus - foreign minister," BBC Monitoring Europe Political Supplied by BBC Worldwide Monitoring, January 5, 2011, date accessed October 6, 2011, http://www.lexisnexis.com.www.libproxy.wvu.edu/hottopics/Inacademic.

${ }_{34}$ Judy Dempsey, "Poles nourish ties to Belarus opposition; Warsaw isn't waiting for EU as it moves to pressure its neighbor," The International Herald Tribune, January 7, 2011, date accessed October 6, 2011, http://www.highbeam.com/doc/1P1-188074059.html.

35 "Radosław Sikorski, Polish Foreign Minister, discusses innovation in foreign policy," last modified April 25, 2011, http://www.youtube.com/watch?v=9T70pOJUbNc.

${ }^{36}$ Ministry of Foreign Affairs of the Republic of Poland, Strategy for Poland's Development Co-operation (2003): 3, http://www.polishaid.gov.pl/files/dokumenty publikacje/Strategy\%20for\%20Polands\%20Development\%20Cooper ation.pdf.
} 
As a result of intense restructuring, Poland since 2004 operates through the framework of development co-operation. That is, Poland works with developing countries around the globe in order to create successful and self-sustaining development in areas where it is most needed. Instituting development co-operation was important for Poland to meet EU standards as well as to ensure the entire process was regulated, transparent, and above all, effective; "[Poland] is also responsible for the processes and actions aimed at socio-economic development and the growth of global prosperity, and that development co-operation should constitute an integral part of Polish foreign policy. ${ }^{, 37}$ Within the program of development co-operation, the money is disseminated via bilateral or multilateral networks. The European Community Budget, European Development Fund, OSCE, United Nations, International Monetary Fund, and World Bank are all multilateral aid entities in which Poland participates. ${ }^{38}$ Because of Poland's obligation to contribute to European Union funds, the multilateral aid contribution is greater than bilateral aid. However, bilateral aid is a more accurate indicator of what the Polish government believes are places worthy of its concern, as the countries who receive bilateral aid are considered to be priority states from the perspective of Polish foreign policy. Polish bilateral foreign aid is concentrated in the categories of technical assistance, financial assistance, food aid, humanitarian aid, and volunteerism. In 2011, the primary objectives for Polish development co-operation were good governance, migrations and border management, rural and agricultural development, and small and medium enterprises (SMEs). ${ }^{39}$

Belarus is consistently one of the largest recipient countries for Polish bilateral aid. For years Belarus has been a preeminent country for Poland. Though the themes may differ from year to year, Poland's primary objectives in support for Belarus have been and continue to be facilitating the construction of civil society in Eastern Europe and introducing European standards and values to the country. ${ }^{40}$ In light of the 2010 election Sikorski promised to increase aid to Belarus

\footnotetext{
${ }^{37}$ Ministry of Foreign Affairs of the Republic of Poland, Poland's Development Co-operation Programme Implemented through the Ministry of Foreign Affairs of the Republic of Poland 2011 (2011): 3, http://www.polishaid.gov.pl/files/inne\%20dokumenty\%20PDF/Pomoc\%20zagraniczna\%202011/Programme2011 PL.pdf.

${ }_{38}$ Strategy for Poland's Development Co-operation, 10.

${ }^{39}$ Poland's Development Co-operation Programme 2011, 4.

${ }^{40}$ Ministry of Foreign Affairs of the Republic of Poland, Poland's Development Co-operation Annual Report-2004 (2005): 20-2, http://www.msz.gov.pl/files/docs/pomoc_pwr_en.pdf.
} 
by approximately PLN 10 million. ${ }^{41} 2011$ would be the highest amount of aid ever given to Belarus, with approximately PLN 42 million planned for the fiscal year. ${ }^{42}$

The goal of Polish aid to Belarus in 2011 is directed towards creating and strengthening civil society. ${ }^{43}$ Where is the money going? Lukashenko has demonstrated he will respect neither democratic principles nor the civil liberties of his people; aid does not go to the government as that would support an illiberal regime. Therefore, the Polish government has concluded that the more effective way to empower the Belarusian citizenry is by assisting and collaborating with NGOS, independent media services, and other institutions; "by partnering with... Belarusians, Polish NGOs assist rather than act. They share responsibilities and are part of the decisionmaking process about project implementation." ${ }^{.44}$

Polish bilateral aid is given to a variety of NGOs and other organizations. In April 2011 the Polish MFA gave more than PLN 5 million to a number of organizations through the special competition held known as "Support for Belarusian Society 2011." 45 These grants covered such themes as civil society, independent media, entrepreneurship, youth and exchanges, education, human rights, and infrastructure. Another competition, "Development Aid 2011", gave an additional nine NGOs approximately PLN 2 million. ${ }^{46}$

\footnotetext{
41 Judy Dempsey, "Belarus: Promises of Aid for Opposition," The New York Times, February 3, 2011, date accessed October 6, 2011, http://www.lexisnexis.com.www.libproxy.wvu.edu/hottopics/Inacademic.

42 Patryk Kultys, e-mail message to author, October 25, 2011.

43 Justyna Bartkiewicz-Godlewska, email to author, September 28, 2011.

${ }^{44}$ Paulina Pospieszna, "When Recipients Become Donors," Problems of Post-Communism 57 (2010): 8.

${ }^{45}$ SEE APPENDIX I.

46 “Wyniki Konkursu 'Pomoc Rozwojowa 2011'," date accessed October 7, 2011, http://www.polskapomoc.gov.pl/Wyniki,konkursu,Pomoc,rozwojowa,2011,1048.html.
} 


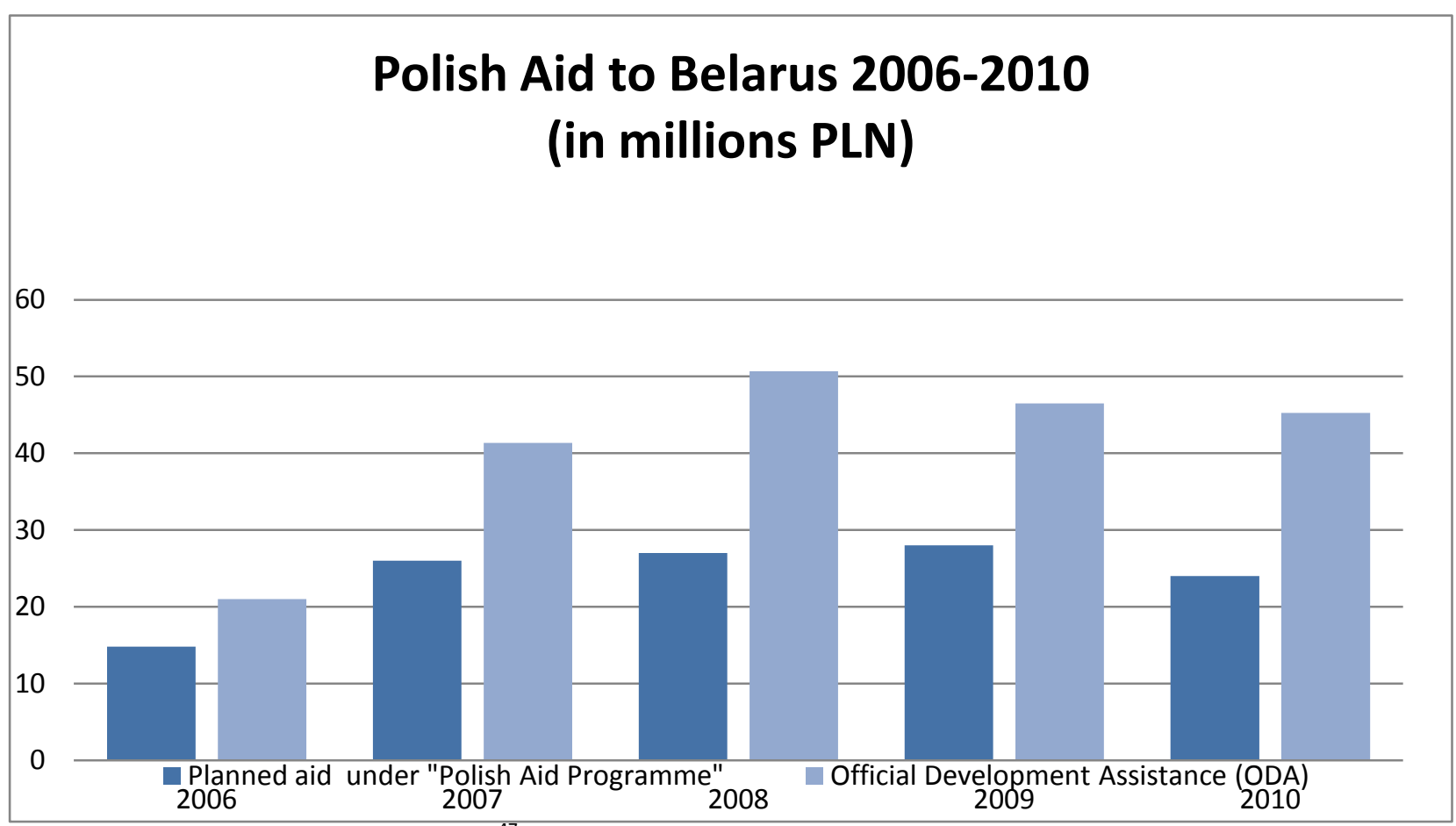

Source: MFA of the Republic of Poland ${ }^{47}$

The graph above shows the amount of money devoted to Belarus since 2006. Money under the Polish Aid Programme represents the money given to independent media, NGOs, and local administrative bodies. Official Development Assistance is defined by the Organisation for Economic Co-operation and Development's Development Assistance Committee (DAC). In addition to the funding provided by the Polish Aid Programme, this amount includes bilateral aid and loans. To be considered a loan, at least 25 percent of the total sum of the loan is in the form of a donation. ODA also takes into account money given to all ministries, not just the Ministry of Foreign Affairs. At the time of writing this thesis, the Polish MFA published an online brochure on development co-operation in 2012. PLN 23.5 million was allotted to Belarus and supporting the priority areas of independent media and civil society and aiding "disadvantaged" society.

\footnotetext{
47 The figures presented do not include funding given for projects carried out by the Embassy of Poland in Belarus, as that information is restricted.
} 


\section{Polish assistance to NGOs and other institutions}

Non-governmental organizations, think tanks, and other "third sector" entities in Poland are some of the most active in the world when it comes to Belarus. These organizations both conduct research on Belarus and partner with organizations in Belarus with the intent of creating a vibrant civil society and promoting democracy. Out of the 54 member organizations affiliated with Grupa Zagranica, an association of Polish-based NGOs, over half of them specifically mention Belarus as a target country for their operations. ${ }^{48}$ These types of organizations receive millions in aid from the Polish government to fund their efforts.

While Polish bilateral aid is given to institutions that are carrying out a litany of projects concerned with all facets of democratization of Belarus, independent media is overwhelmingly the largest recipient of MFA assistance. When speaking of independent media for Belarus, there are three main examples: Belsat TV, Radio Racja, and European Radio for Belarus. All three receive funding from the Polish government, but Belsat TV receives by far the greatest share of money. In 2010, out of the PLN 24 million that was set aside for Belarus, PLN 16 million went to Belsat TV. ${ }^{49}$ Not only is Belsat TV the main benefactor of Polish governmental assistance, but the Polish government is the primary financer of Belsat TV. ${ }^{50}$ The very existence of Belsat would not be possible if it were not for the Polish government. Belsat TV was launched in 2007 as a joint initiative between the Polish MFA and Telewizja Polska, or Polish Public Television. Based in Warsaw but broadcasting to Belarus and elsewhere, Belsat TV was the first television station to broadcast exclusively in the Belarusian language and continues to be the only source of independent and unbiased source of news for Belarus on TV. Belsat TV is watched by approximately 10 percent of the population of Belarus, and almost 25 percent of Belarusians with satellites. $^{51}$

A foreign editor from Belsat TV was gracious enough to be interviewed for the purpose of this thesis. In the conversation, he stressed that Belsat TV and other independent media outlets are important for not only the Belarusian population but also for instilling proper practices, ethics, and integrity amongst Belarusians engaged in the media profession. Upon return to their country, Belarusian journalists that participate in foreign study visits or exchanges have few

\footnotetext{
48 “About Zagranica Group," last modified 2011, http://zagranica.org.pl/en/Kim-jestesmy/.

49 “Białoruś- Projecty 2010," last modified August 23, 2011, http://www.polskapomoc.gov.pl/files/Kraje\%20priorytetowe/BIALORUS 2010 lista\%20projektow.pdf.

${ }^{50}$ Jakub Biernat, e-mail to author, October 24, 2011.

51 "About Us," last modified 2010, http://belsat.eu/en/o nas/.
} 
places to work other than the propaganda machines of state-run TV and radio stations. Having a career in media is a hazardous occupation in Belarus, as the government frequently targets independent or investigative journalists with harassment, intimidation, and incarceration to control the flow of information reaching the public. Belsat TV and others provide a place to work and continue their work as not only committed journalists but also as concerned citizens aspiring to free their country from the grips of authoritarianism.

What is the relationship between the Polish government and these organizations? In order to answer this, a questionnaire was sent out to a variety of Polish-based groups that are engaged in Belarusian affairs. In addition to an editor from Belsat TV, the respondents include a specialist from the Centre for Eastern Studies, a state-run analysis center; a project coordinator from the Robert Schumann Foundation of Poland; a program director from the German Marshall Foundation; and a program officer from a non-profit not affiliated directly with the Polish government but also involved in assistance to Belarusian free media and civil society. From those who either cooperated with or received financial assistance from the Polish government, the impression was generally positive. In their professional experience, the Polish government is committed to the democratization of Belarus, and is open to the recommendations and suggestions of experts and specialists working with such components of democratization and the construction of civil society, media, youth exchanges, and political opposition. Those who replied said more often than not their "voice was heard" at the higher political levels, and that the national government took into account many different opinions from various sources in formulating their policy towards Belarus.

Not everyone had such a glowing perspective of the Polish government. The program officer outside of the Polish government's influence was much more candid and disparaging about Poland's role in supporting Belarusian civil society. One criticism he made was the very short timeframe given to NGOs to produce results within the grant cycle. By the time the grants are funded, recipients only have the summer months to implement their projects before the time comes for end-of-the-year reporting. One cannot expect much progress to be made in such a short period of time, particularly with such undertakings as constructing civil society, a very long-term and complicated endeavor. Another observation given by him is that the Polish government's operations in Belarus are ambiguous and shrouded in mystery. Aside from the money reported in development co-operation reports and earmarked in the federal budgets, few 
outside of a select group within the Polish government know to whom the money is going in Belarus, if at all. This arouses suspicion of the Polish government's activity in Belarus and feeds into the Lukashenko's conspiracy theory that the Polish government is aiding subversive groups in order to stage a coup and destabilize the country.

\section{Education and Scholarships}

In addition to civil society institutions, the Polish government is reaching out to future generations of Eastern Europeans through stipends and scholarship funds for students. For Belarusian students specifically, in 2006 the Polish government created the Konstanty Kalinowski Scholarship Programme. The scholarship is available for any Belarusian student for the nine-month academic year, but full-year scholarships for up to five years are available for Belarusian students that have been expelled from their home institutions for political reasons. The scholarship covers tuition, accommodation, and any fees for documentation and insurancePLN 1,240 is given to students every month to cover living expenses. The scholarship is applicable for all areas of studies and at all public institutions of higher education in Poland; 360 students were awarded the Konstanty Kalinowski scholarship for the 2011/2012 academic year, and as a result are receiving an education unavailable to them in Belarus. ${ }^{52}$

The Kalinowski scholarship provides an important opportunity to Belarusian students, particularly those who otherwise could not pursue their studies because of the Belarusian regime. Unfortunately, few scholarships like it exist. Using the example of the Centre for Eastern Studies at the University of Warsaw, there are seven scholarship opportunities that receive funding from the Polish government that are available for Belarusian students. However, these scholarships are given to a handful of students annually and are open to all students from Eastern Europe, Russia, the Balkans, the Caucasus region, and Central Asia. Therefore, these scholarships are highly competitive. If a student is fortunate enough to receive one of these scholarships, the amount awarded is small and would barely cover living expenses in Warsaw. Additionally, the scholarships do not cover travel expenses, insurance, visas or residency permits, or accommodation. It is foreseeable that these scholarships would end up as supplemental income

\footnotetext{
52 "Zasady Korzystania z 'Programu Stypendialnego im. Konstantego Kalinowskiego'," last modified 2011, http://www.studium.uw.edu.pl/ filez/Regulamin\%20Programu\%20im\%20\%20Konstantego\%20Kalinowskiego.pdf.
} 
to students that are wealthy enough to study abroad or receive their education at a foreign university.

In addition, the Polish language obligations could also be problematic. Many of the scholarships reviewed contain stipulations about submitting a thesis in Polish at the end, or attending Polish lectures after the first year. Language courses are provided as part of the scholarship, but even still this seems to require an exceptional mastery of the Polish language in a very short period of time. Since many of the applicants probably have more experience in the English language than the Polish language, scholarship recipients should be able to have greater flexibility after the second year if they would like to study and write in Polish or continue with English as their working language.

\section{Conclusions}

When communism fell, Poland was determined to aid Eastern Europe in the democratic transition, Belarus included. Poland took the lessons learned from its own transition and applied them to its assistance towards Belarus's politics, economy, and society. Progress was made, but after Lukashenko came to power Poland-Belarus relations became frosty at best. With Poland moving towards the west and Belarus moving towards the east, the border between them metaphorically grew wider. Tensions between the two countries were strong in the 2000 s due to the oppression of the Polish minority by Belarusian authorities and the retreat from democratic reform in the country. Therefore, Poland is trying to skip over Minsk and reach the Belarusian people. Poland is doing this through channeling millions in assistance to Belarusian NGOs, TV and radio stations, think tanks, and others. It is natural that Poland would target civil society as the solution for Belarus because in Poland it was the actions by its own resilient civil society that brought down communism. By supporting the population, Poland hopes to initiate change in Belarus from the bottom-up rather than trying to persuade an egomaniacal, obstinate despot to change.

It is difficult to assess success in a situation such as that prevailing in Belarus because success is ultimately relative. A pessimist would see Belarus as an example of failed Polish/ western external intervention because Lukashenko is still in power and the Belarusian populace is still confined by authoritarianism. Contrarily, the fact that despite seventeen years of Lukashenko, there are still strains of opposition and dissent within Belarus is by virtue a success. 
In the context of constructive Polish support for Belarus, one must delineate Polish civil society from the Polish government. After considerable research and deliberation, I have found that the Polish government has indirectly accrued a certain level of success through its support of Polish NGOs and other groups whose efforts are directed towards Belarus. The depth of Polish civil society activity in Belarus covers a wide-array of themes, from the environment to entrepreneurship. Cooperation between these groups and their counterparts in Belarus empowers Belarusians and provides them with knowledge, experience, and opportunities that are either anemic or non-existent in their own country.

Though the efforts of these organizations would not be possible without this funding, in a strictly political sense the Polish government has made a number of gaffes that undermine democratization in Belarus. For instance, in 2011 the Polish government handed over financial information that was used in the arrest of human rights advocate Ales Bialatski. ${ }^{53}$ Also that year, as stated before, Poland waived the visa fee for Belarusians travelling to Poland. While the fee may be waived, the application process is the same. Belarusian citizens need a personal invitation to travel to Poland. Also, Polish consulates are hesitant of allowing people, even ethnic Poles, employed by the Belarusian government into Poland. In a country where the vast majority of citizens are employed by the State, only a few benefit from this "new" visa policy. If anything, travel between Belarus and Poland is as difficult as ever.

In this chapter, the development co-operation framework and Polish aid to Belarus was emphasized because of Poland's persistent boasting that it is providing generous support and assistance to democratization in Belarus. However, upon further scrutiny, the system has a significant transparency deficit. From a researcher's perspective, the Polish aid system is confusing and unclear. Both in Polish and in English, the documents available on the official website, polishaid.gov.pl, are spotty and do not cover every year. The documents that are available often have different sums of assistance, and it is quite difficult to understand what is included and what is not included in any given total. To some extent, this is understandable considering that the development co-operation is a recent addition to the Polish governmental budgetary framework. Nevertheless, the reporting on development co-operation is important for

\footnotetext{
${ }^{53}$ Jeremy Druker, "And now Poland is complicit as well," East of Center: Transitions Online Regional Intelligence Editors' Blog, August 19, 2011, http://eastofcenter.tol.org/2011/08/and-now-poland-is-complicit-as-well/.
} 
the public and others to know that the money given is put to good use. Therefore, the system has a way to go in terms of accessibility and clarity.

The problems of the Polish minority in Belarus were also prominent in this chapter. In this author's opinion, the Polish minority in Belarus has played too strong of a role in shaping Poland's foreign policy towards Belarus. The failed dialogue in 1990 and the ZPB conflicts in 2005 and 2010 demonstrated that the Polish government has seemed to be most interested in Belarus when the Belarusian Poles are disenfranchised in some way. This was particularly true in during the Ivanets dispute because Poland at the time was governed by the more nationalistoriented Kaczyński government; with the rhetoric and actions coming from Warsaw in terms of sanctions and support, Belarusians and others got the impression that Poles were just looking out for their own.

Finally, the Polish government has acted unilaterally at times when it was imprudent to do so. In its public rhetoric, Poland presented itself as the vanguard of Belarusian democracy. Yet when the European Community imposed political sanctions, Poland disagreed, and when the EU wanted to take stronger action against Lukashenko following the 2010 election, the Polish government waivered. This lack of cohesion amongst foreign actors has created a fragmented political landscape in Europe and Lukashenko has exploited this in order to preserve his power. However, this is not necessarily anyone's fault as it is largely symptomatic of the changing political conditions in Europe. Since the fall of communism the continent has seen dramatic changes. The European Union is largely responsible for these changes, but because the Union is such a unique experiment in modern international relations, it's constantly evolving. It is only in the past few years that that EU is beginning to synthesize foreign policy of the Member States with the intentions of forming a coherent, united voice in the world and with third-party actors. This chapter covered the period in which Poland joined the European Union, and after seven years of membership Poland has adapted many aspects of its foreign policy to conform to a more pan-European outlook. In the next chapter, the actions of the European Union towards Belarus will be reviewed as well as how Poland is contributing to them. With such a large institution as the European Union, does the old adage "strength in numbers" apply? 


\section{CHAPTER 3: ESTRAGEMENT VS ENGAGEMENT: \\ The European Union's Past, Present, and Potential \\ Strategies towards Belarus, and How Poland Can Help}

While the previous chapter analyzed Belarus's relationship with its immediate neighbor to the west, Poland, this chapter will expand the geopolitical scope and examine Belarus's relationship with its much larger neighbor to the west, the European Union. While Poland has persistently maintained some degree of interaction with Belarus after 1991, the EU froze out the country in its external policy when it became clear that Belarus (or rather, Lukashenko) was unwilling to implement political and economic reform. ${ }^{1}$ However, the European Union reexamined its position towards Belarus after 2001. The change in opinion occurred, among other reasons, because of an assessment by the OSCE that isolation by the EU and the greater international community was neither beneficial to the Belarusian people nor reforms in the country. ${ }^{2}$ This recommendation came at a time when the European Union was evaluating its external relations with all of its surrounding countries, particularly in light of the impending 2004 EU enlargement. This shift led to a revised approach within the EU's Belarus strategy.

Unfortunately, the obstinate nature of Belarus's ruling regime created a pattern of "one step forward, two steps back." The European Union would make some headway with a seemingly compliant Lukashenko, only to be rebuffed with further violations of human rights and civil liberties and continued authoritarian rule. Currently, the EU is experimenting with a number of initiatives designed to strengthen the ties between Europe and the east. Belarus's participation is important, but the European Union has repeatedly said that further integration into the European system is contingent on a number of reforms. Since 2004, Belarus has been on the doorstep of the EU, but will Belarus come knocking?

This chapter will begin with a timeline of the EU's relationship with Belarus and the various methods it has used to set it on a more European/ western trajectory. Particular attention will be paid to the European Union's current programs, the European Neighborhood Policy and the Eastern Partnership (aimed specifically at Eastern Europe and the South Caucasus). For the purposes of this thesis, Poland's role in these programs will be an important component to the

\footnotetext{
${ }^{1}$ Giselle Bosse, "Challenges for EU governance through Neighbourhood Policy and Eastern Partnership: the values/ security nexus in EU-Belarus relations," Contemporary Politics 15 (2009): 216.

2 "Chronology of bilateral relations," last modified 2009, http://eeas.europa.eu/delegations/belarus/eu_belarus/chronology/index_en.htm.
} 
overall analysis. The chapter will conclude with an appraisal of the efforts made by the European Union, the current outlook on prospective relations between Belarus and the European Union, and where Poland fits in all of it.

\section{European assistance to Belarus during the 1990s}

As mentioned in the introduction, diplomatic interaction between the European Union and Belarus was brief following Belarus's independence. As with other former Soviet republics, the European Union drafted a Partnership and Cooperation Agreement (PCA) with Belarus. The PCA would create new standards in trade, establish formal diplomatic and political relations, and guarantee that assistance delivered by Europe to Belarus was appropriately used as well as reflected progress in reforming the political and economic sectors. ${ }^{3}$ A PCA was drafted with Belarus, but after Lukashenko won the presidency it was never fully ratified. In addition, after the controversial elections in 1996, the European Union instituted the first round of sanctions against Belarus and travel restrictions for select members of the ruling elite.

Though the European Union's efforts to negotiate with Lukashenko and his administration were abandoned after 1997, this did not mean that Belarus as a whole was excommunicated. The country was still eligible for the EU's Technical Aid to the Commonwealth of Independent States (TACIS) program. TACIS was the framework through which financial assistance to CIS states was disseminated. The mission behind TACIS was to first create an environment conducive to a market economy. With a stable economic situation, it was assumed that democratic consolidation and good governance would ensue. ${ }^{4}$ This was especially the case for Belarus, where the focus of technical assistance was to be a catalyst for democratization. As Belarus was also deeply affected by the nuclear meltdown in Chernobyl, millions of euros were given in the form of humanitarian and food aid. In total, Belarus received $€ 221$ million in aid from the EU between 1991 and $2004 .^{5}$

\footnotetext{
${ }^{3}$ Kerri Longhurst, "Introducing the Eastern Partnership-Implications for the European Neighborhood Policy," in Forging a new European Ostpolitik-an Assessment of the Eastern Partnership (Warsaw: Collegium Civitas Press, 2009), 10.

${ }^{4}$ Ibidem.

${ }^{5}$ European Commission, European Neighbourhood and Partnership Instrument Belarus- Country Strategy Paper 2007-2013 and National Indicative Program 2007-2013, 15-16, http://ec.europa.eu/world/enp/pdf/country/enpi_csp_nip_belarus en.pdf.
} 
Technical assistance to Belarus did not produce the level of progress that was initially desired; both sides were culpable. In Belarus, Lukashenko wanted minimal international intervention in Belarus, particularly from the European Union and the United States, because of their presumed pre-existing prejudices and a strong distrust of western intentions. This was not necessarily an unwarranted fear, since the stipulations demanding political reform would undoubtedly compromise Lukashenko's hold on the presidency. Therefore, he made it very difficult for any technical assistance or foreign aid to reach the targeted recipients. ${ }^{6}$ The bureaucratic process in Belarus is lengthy and complicated, and because of such disincentives in place to inhibit assistance from abroad, there was generally a lack of knowledge and capabilities amongst the Belarusian population to effectively utilize the available funds. ${ }^{7}$ On the European side, the bureaucracy was also a deterrent. The processing period is long, and even the EU admits that their methods are somewhat inflexible; the requirements were rather grandiose, the rules for delivery were too stringent, and the outlined objectives were unrealistic for Belarus's situation. ${ }^{8}$ The quantity of funding was also problematic. The amount of aid given to Belarus from 1991 to 2006 made the European Union Belarus's largest external source of assistance. ${ }^{9}$ However, this amount is paltry relative to the money given to Russia and Ukraine, which together received around 75 percent of all TACIS funds. ${ }^{10}$ Even with assistance going to the country, Belarus was no closer to embracing democracy.

\section{Belarus as part of the European "Neighbourhood"}

In the early 2000s, the European Union's attitude towards the surrounding countries began to change. As the EU was destined to expand its borders and include a diverse range of new territories and border an even more diverse set of new countries, the role it played in the region took on a new and important outlook. Ten years after the collapse of communism, the political and economic landscape of Central and Eastern Europe was far from uniform. There

\footnotetext{
${ }^{6}$ Alena Rakava, "Evaluation of the Previous Programmes of the European Union (TACIS, NGOS, Cross-Border Cooperation, etc.)," in Belarus-Towards a United Europe, ed. Mariusz Maszkiewicz (Wrocław: Jan NowakJeziorański College of Eastern Europe, 2009), 45.

${ }^{7}$ Vyachaslau Pazdnyak, "Expanding European neighbourhood menus for Belarus," Belarus-Towards a United Europe, 28.

${ }^{8}$ European Neighbourhood and Partnership Instrument Belarus, 17.

9 "Coordinating Unit for the European Union's TACIS Programme in the Republic of Belarus," date accessed December 3, 2011, http://cu4eu.net/en/.

${ }^{10}$ Rakava, 44.
} 
were the hailed success stories of Central Europe and the Baltic States, the failure to democratize in Belarus, and the in-between, quasi-democratic states such as Ukraine and Georgia. With the EU growing in not only size but in power and influence, a new strategy was needed.

This evolution in thinking about EU external relations led to the advent to the European Neighbourhood Policy (ENP). The policy was designed to create a zone of stability and prosperity within the European sphere, specifically along the Mediterranean Sea, in the Near East, and in the Eastern Europe/ South Caucasus region:

"The privileged relationship with neighbours will build on mutual commitment to common values principally within the fields of the rule of law, good governance, the respect for human rights, including minority rights, the promotion of good neighbourly relations, and the principles of market economy and sustainable development."11

Because of the variety of countries and cultures involved, Country Strategy Reports and Action Plans were made on a case by case basis with each country to ensure that the EU was appropriately addressing the specific problems and opportunities of each state. Essentially, through a multilateral framework, the European Union looked to improve bilateral relations with those countries bordering EU territory.

Belarus is not a full participant in the ENP; like before, full engagement and access to ENP resources is contingent on political and economic reform occurring in the country. Nevertheless, similar to TACIS, technical assistance and humanitarian aid is still given to Belarus, only now it is disseminated through the European Neighbourhood and Partnership Instrument (ENPI). Via the ENPI, Belarus received $€ 5$ million a year (approximately $€ 0.50$ per capita). ${ }^{12}$ In order to assess the scope and aim of the ENPI, each country has a prepared National Indicative Programme (NIP) that identifies key areas of interest and need for each country covered. The NIP amount for Belarus was €46 million between 2007 and 2011. Once again, this amount was low compared to other countries. Moldova, a country with half the population, received $€ 210$ million, and Ukraine received $€ 470$ million between 2011 and 2013 alone. ${ }^{13} 14$

\footnotetext{
${ }^{11}$ Commission of the European Communities, European Neighbourhood Policy Strategy Paper (2004): 3, http://ec.europa.eu/world/enp/pdf/strategy/strategy paper en.pdf.

${ }^{12}$ European Neighbourhood and Partnership Instrument Belarus, 4.

${ }^{13}$ Commission of the European Communities, Progress Report Republic of Moldova (2009): 21, http://ec.europa.eu/world/enp/pdf/progress2009/sec09 514 en.pdf.

14 “EU supporting Ukraine's reforms with €470.05 million in 2011-2013," last modified 2011, http://www.enpiinfo.eu/files/publications/Ukraine\%20NIP\%202010.pdf.
} 
Despite the disappointing results from TACIS support to Belarus, the theory behind the ENPI and the NIP is almost identical: by cultivating favorable economic and social conditions in the country, democracy will follow. Regardless of the rhetoric from Brussels concerning the importance of building democracy in Belarus, out of the $€ 46$ million earmarked for Belarus under the 4-year NIP period, only $€ 3.5$ million per year was reserved for democratic development and good governance. ${ }^{15}$ Most of the money went towards privatization efforts and alleviating the lingering effects of Chernobyl on the population.

The European Neighbourhood Policy proved to be yet another impotent program in bringing Belarus into the European sphere of influence. However, in 2008 there was renewed hope in what was starting to look like a lost cause. In Belarus, Lukashenko revised his foreign policy to be more "multi-vectored," looking in other directions than the east. Though the considerable money available to Belarus from the European Union was no doubt a factor in this decision, Lukashenko's change of attitude was overwhelmingly due to the degenerating relationship with Russia.

Lukashenko grew bitter over Russia's indifferent attitude towards the Russia-Belarus Union, which for years was the focal point of his presidency. ${ }^{16}$ Likewise, Russia became disheartened with Belarus and its waning support. Belarus's noncommittal disposition became obvious when Belarus was reluctant to recognize the breakaway provinces of South Ossetia and Abkhazia. The most crushing blow to Russia-Belarus relations, however, was the energy dispute at the end of 2006. Belarus's economic "success" is dependent on the copious amount of natural gas and petroleum received from Russia at drastically reduced rates. When Russia demanded that Belarus start paying regular prices for energy imports, Lukashenko was outraged. The dispute was eventually mitigated, but not without a few humiliating concessions by Belarus; the price of gas was to increase gradually until Belarus was paying market value. In addition, 50 percent of the shares of Beltransgaz, Belarus's state energy company, were sold to Russian-owned Gazprom. ${ }^{17}$

With Russia no longer being the reliable partner (i.e. subsidizer) it once was Lukashenko was forced to look elsewhere for support. Therefore, his new strategy was to turn to the west in

\footnotetext{
${ }^{15}$ European Neighbourhood and Partnership Instrument Belarus, 24.

${ }^{16}$ Marples, "Belarus-Russian Union," 31.

17 "Russia Belarus Gas Pricing Row Sparks Jitters in Europe," last modified December 29, 2006, http://www.dwworld.de/dw/article/0,22293767,00.html.
} 
hopes of receiving handouts from European coffers in Brussels. To appease the EU's nagging demands for reform in his country, Lukashenko made some changes. For instance, in 2008, the For Freedom movement led by prominent anti-Lukashenko activist and 2006 presidential candidate, Aleksandr Milinkevich, was officially registered in Belarus. ${ }^{18}$ Lukashenko also released a number of political prisoners and dabbled in moderate economic liberalization. ${ }^{19}$ In public, the Belarusian president spoke more favorably of the European Union and called for closer cooperation in a variety of sectors. The European Union, excited to finally see a more collegial Lukashenko, responded in full. In 2008, the Union relaxed the travel bans it had imposed upon certain members of the Belarusian government. An official European Commission document called "What the EU Can Bring to Belarus" outlined benefits of EU-Belarus cooperation that could be achieved only once the Lukashenko government accepted twelve points of democratization; as a gesture of compromise, these twelve points were reduced to five. ${ }^{20}$ More importantly, however, was the agreement made in 2008 to install a permanent EU representative office in Minsk. The Delegation of the European Union to Belarus as it is officially called sent a strong message that the EU was committed to forging a new, closer relationship with Belarus. ${ }^{21}$ This series of confidence-building events culminated with the EU Commissioner for External Relations and European Neighbourhood Policy, Benita FerreroWaldner, making an official visit to Minsk. Ferrero-Waldner met with Lukashenko and extolled the steps happening in Belarus towards building a legitimate democracy. ${ }^{22}$ Not only did the European Union laud Lukashenko for his good behavior, more money was also channeled to Belarus. For the 2007-2010 NIP period, the budget for Belarus went from $€ 20$ million to $€ 30$ million, and an additional $€ 16$ million was set aside for the year 2011 . $^{23}$

\footnotetext{
${ }^{18}$ Valera Ruselik, “Belarusian 'For Freedom' movement registered. What next?” last modified December 19, 2008, http://humanrightshouse.org/Articles/9468.html.

${ }^{19}$ Anna Zielińska and Kerri Longhurst, "The Eastern Partnership-Context and Reaction from a Troubled Neighbourhood," in Forging a new European Ostpolitik - an Assessment of the Eastern Partnership (Warsaw: Collegium Civitas Press, 2009), 33.

${ }^{20}$ Bosse, 222.

21 "About Us," last modified 2011, http://eeas.europa.eu/delegations/belarus/about us/welcome/index en.htm

22 "Commissioner Benita Ferrero-Waldner visits Belarus to encourage further steps towards democratisation, assistance package of $€ 10$ mil announced," last modified June 19, 2009, http://europa.eu/rapid/pressReleasesAction.do?reference=IP/09/970\&format=HTML\&aged=0\&language=EN\&guiL anguage $=e n$.

${ }^{23}$ European Neighbourhood and Partnership Instrument Belarus, 24.
} 
While the public discourse emanating from the EU and Belarus was optimistic, the reality was something different. The "reform" taking place in Belarus was largely cosmetic; the political environment was still very hostile towards opposition groups and civil society. At the beginning of 2009, the European Parliament adopted a resolution acknowledging the progress made in Belarus, but also reiterated that much more work was needed on behalf of Lukashenko's government in the fields of political pluralism, economic liberalization, and respect for human rights and minorities (the ZPB affair and the treatment of Belarusian Poles was specifically mentioned). ${ }^{24} \mathrm{~A}$ few months later, the Parliament also reinstated the travel bans on Belarusian officials that were lifted the previous year. ${ }^{25}$ EU-Belarus relations thawed somewhat, but aside from a few lofty (and empty) proclamations both Brussels and Minsk were evading concrete discussion on real change.

\section{The Eastern Partnership: promises and compromises}

Lukashenko's willingness to comply with European standards was superficial. But encouraged by the moderate level of progress, the European Union included Belarus in the new project within the European Neighborhood Policy known as the Eastern Partnership (EaP). The idea for an eastern component was in response to the new direction taken by the Neighborhood Policy that propagated a more regionalized approach. Already in place was the Union of the Mediterranean (UfM) that focused on North Africa and the Near East, and the Northern Dimension that covered the Nordic countries, the Baltic States, and Russia. ${ }^{26}$ The Eastern Partnership involves the EU and six countries: Ukraine, Moldova, Belarus, Azerbaijan, Armenia, and Georgia. The intent of the EaP is to strengthen and deepen the EU's ties and influence in the region. Like the overarching ENP, the idea is that through multilateral cooperation, bilateral relations between the EU and these countries will grow stronger. The EaP functions on the basis of four platforms: democracy, good governance, and stability; economic integration and

\footnotetext{
${ }^{24}$ European Parliament, European Parliament resolution of 15 January 2009 on the EU strategy towards Belarus 2009): 3, http://www.europarl.europa.eu/meetdocs/2009 2014/documents/depa/dv/depa 20100310038 /depa 20100 310038 en.pdf.

${ }^{25}$ European Parliament, European Parliament resolution of 2 April 2009 on bi-annual evaluation of the EU-Belarus dialogue (2009): 1, http://www.europarl.europa.eu/sides/getDoc.do?pubRef=-//EP//NONSGML+TA+P6-TA-2009$0212+0+\mathrm{DOC}+\mathrm{PDF}+\mathrm{V} 0 / / \mathrm{EN}$.

${ }^{26}$ Kerri Longhurst, Forging a New European Ostpolitik-An Assessment of the Eastern Partnership (Warsaw: Collegium Civitas Press, 2009), 5.
} 
convergence with EU sectoral policies; energy security; and contacts between people. ${ }^{27}$ While these are all noble causes, since EU interests in this region are motivated by energy, the economic benefits are the driving force. The end goal for the European Union is to conclude bilateral Association Agreements with the participating countries. A step-up from the preexisting PCA, the new Association Agreements "will provide for the establishment or the objective of establishing deep and comprehensive free trade areas... between the EU and partner countries, [which] could in the long-term perspective grow into a network of deep and comprehensive free trade areas." 28

The Eastern Partnership was appealing to many in Europe for its potential. First off, the disputes between the EU and Russia over energy brought into focus Europe's dependence on natural resources from Eurasia. Developing a positive relationship with the countries in this area meant a more stable supply of oil and natural gas. Because of the successes in Central Europe and the Baltic, the EaP theoretically had a greater chance of success than, say, the Union for the Mediterranean; Eastern Europeans were still "Europeans" and their ability to conform to European norms and values was more probable than countries in Africa or the Middle East. Furthermore, at a time when the European economy was sluggish and Europe was rather strapped for cash, the Eastern Partnership, on paper, appeared fairly inexpensive. The money going to the EaP had already been set aside through ENPI (approximately 1/3 of the total funds for ENPI); additional resources would come in the form of credits for the European Investment Bank (EIB) and the European Bank for Reconstruction and Development (EBRD) as well as voluntary contributions from Member States. ${ }^{29}$ Though the EaP funding wasn't going to break the bank, it is still no small sum; the expected funds allotted for the Eastern Partnership are projected to be $€ 785$ million in $2013 .{ }^{30}$ For Belarus, the constructive dialogue between the EU and Lukashenko in 2008 and 2009 made a number of Member States see engagement as a more effective strategy, as isolation wasn't bringing about the type of change Europe wanted to see in Belarus.

\footnotetext{
${ }^{27}$ Council of the European Union, Joint Declaration of the Prague Eastern Partnership Summit (2009): 11, http://www.consilium.europa.eu/ueDocs/cms Data/docs/pressdata/en/er/107589.pdf.

${ }^{28}$ Ibidem, 7.

29 "EU Financial Assistance to the EaP States," last modified 2011, http://www.easternpartnership.org/programmes/general.

${ }^{30}$ Longhurst, 22.
} 
Nevertheless, the Eastern Partnership also faced its share of criticisms. One aspect that weakened the EaP from the very beginning was how the Partnership would fit into the question of EU membership. Countries like Ukraine and Moldova openly expressed their desire to become Member States of the European Union, and thus far have oriented their foreign policy and development to comply with the prerequisites for candidacy. Other states would enjoy the fruits of closer cooperation with the $\mathrm{EU}$, but are undecided if membership is a path they want to take. In Belarus's case specifically, the internal politics and dependence on Russia make membership out of the question, at least for the near future. Regardless of intentions, all partner countries involved in the EaP are far from meeting the prerequisites for EU Member State candidacy as outlined by the Copenhagen Criteria. With the European Union suffering from "enlargement fatigue," the Eastern Partnership represents (for the EU) a comfortable balance of more cooperation without full-fledged integration. For the participating countries, however, there was and still is fear that the formation of the Eastern Partnership will derail aspirations of membership and leave Eastern Europe in EU limbo.

Yet another barrier to the Eastern Partnership's success that has grown stronger in 2010 is the state of the global economy. One of the original goals of the EaP was to introduce economic reform in Eastern Europe and the South Caucasus regions to make them more compatible with the European/ western system. However, the worldwide economic crisis had a very strong impact on Eastern Europe (even Belarus suffered a great deal, which is peculiar since sanctions have made it an outlier in global trade). Therefore, the resources that were intended to institute modernized standards and practices have become bailout funds for plummeting economies. As the European Union is struggling to get its own fiscal house in order, EU Member States are more concerned getting the European Union back on track before they assist their worse-off neighbors. ${ }^{31}$ The Eastern Partnership is promising on paper, but these and other factors are making the actual efficacy of the program extremely difficult.

\footnotetext{
${ }^{31}$ Pavel K. Baez, "Russia and the EU Eastern Partnership: Cannot Stop It but Loathe It," Forging a new European Ostpolitik (Warsaw: Collegium Civitas Press, 2009), 74.
} 


\section{The Polish factor in EU-Belarus relations}

Though the interest in Eastern Europe has been a rather recent phenomenon in Brussels, Poland has long been an advocate for a stronger EU policy towards Eastern Europe. ${ }^{32}$ In many ways Poland is leading by example. Poland saw its transformation into a free-market democratic state as a model for other states to follow, particularly those in Eastern Europe. Organizations such as the Polish Know-How Foundation provided aid as well as technical assistance and expertise to transitional democracies for years. ${ }^{33}$ When Poland incorporated the development cooperation framework as the institutional system for delivering aid, Eastern Europe was a top priority from the very beginning. ${ }^{34}$ Poland claims that it is one of the most ardent supporters of Belarus at the European level, but is there substantial evidence to support this? If one scrutinizes financial assistance to Belarus, Sweden is by far the largest donor within the European Union. ${ }^{35}$ Moreover, the ENP Country Strategy Paper for Belarus defines 21 categories of need in Belarus (democracy-building, independent media, legal development, etc.). Poland supports four of these categories, while Latvia and Lithuania, two other EU countries that border Belarus, support twelve and eight respectively. ${ }^{36}$ In words, Poland has frequently called for Western Europe deepening ties with the east, but has that translated into action from the Polish government at the EU level?

The Eastern Partnership, by far Europe's most ambitious program in Eastern Europe since the collapse of the Soviet Union, would not have happened if it wasn't for Poland; "For Poland, the EaP kick-off is the result of a longstanding campaign to embolden the Union's eastern policy, a drive which began when Poland wasn't yet a member of the EU." ${ }^{37}$ The proposal for the Eastern Partnership was sponsored by the Polish and Swedish governments, with auxiliary support from the Czech Republic under whose EU presidency period the EaP was launched. ${ }^{38}$ Though all parties deserve their share of credit, Poland has without a doubt been the strongest proponent for the Eastern Partnership since its inception. In November 2010, a month

\footnotetext{
${ }^{32}$ Zielińska and Longhurst, 29.

33 "Meeting of the Board of the Polish Know-How Foundation," last modified July 1, 2011, http://www.polskapomoc.gov.pl/Meeting,of, the,Board, of, the,Polish,Know,How,Foundation,1180.html.

${ }_{34}^{34}$ Poland's Development Co-operation Programme 2011, 6.

${ }^{35}$ Dr. Joerg Forbrig, e-mail to author, October 19, 2011.

36 "European Neighbourhood and Partnership Instrument Country Strategy Paper 2007-2013: Belarus," Annex V.

37 Joanna Popielawska, "The Eastern Partnership in the Context of Other EU Regional Initiatives in the East" Forging a new European Ostpolitik, 51.

${ }^{38}$ Carl Bildt, "The European Union Eastern Partnership, Energy Security and U.S.-EU Cooperation" (speech given at the Brookings Institution, Washington, D.C., November 2, 2009).
} 
before the presidential elections in Belarus, Sikorski visited the country stating that it was imperative for the elections to meet international standards of fairness and transparency. Not only would future prospects of cooperation within the Eastern Partnership be on the line, but if accomplished a $€ 3$ billion loan from the EU would be waiting for Belarus afterwards. ${ }^{39}$ More and more, Polish officials represent the public face for the Eastern Partnership, and Sikorski in particular has assumed the dual character of Polish Foreign Minister and EU ambassador to Eastern Europe.

\section{The 2011 Polish Presidency of the EU}

From a synergetic perspective, 2011 looked to be an important year for the Eastern Partnership. This was not only the year of the Eastern Partnership Summit, but also the Polish Presidency of the Council of the European Union. With an important meeting set to occur at the

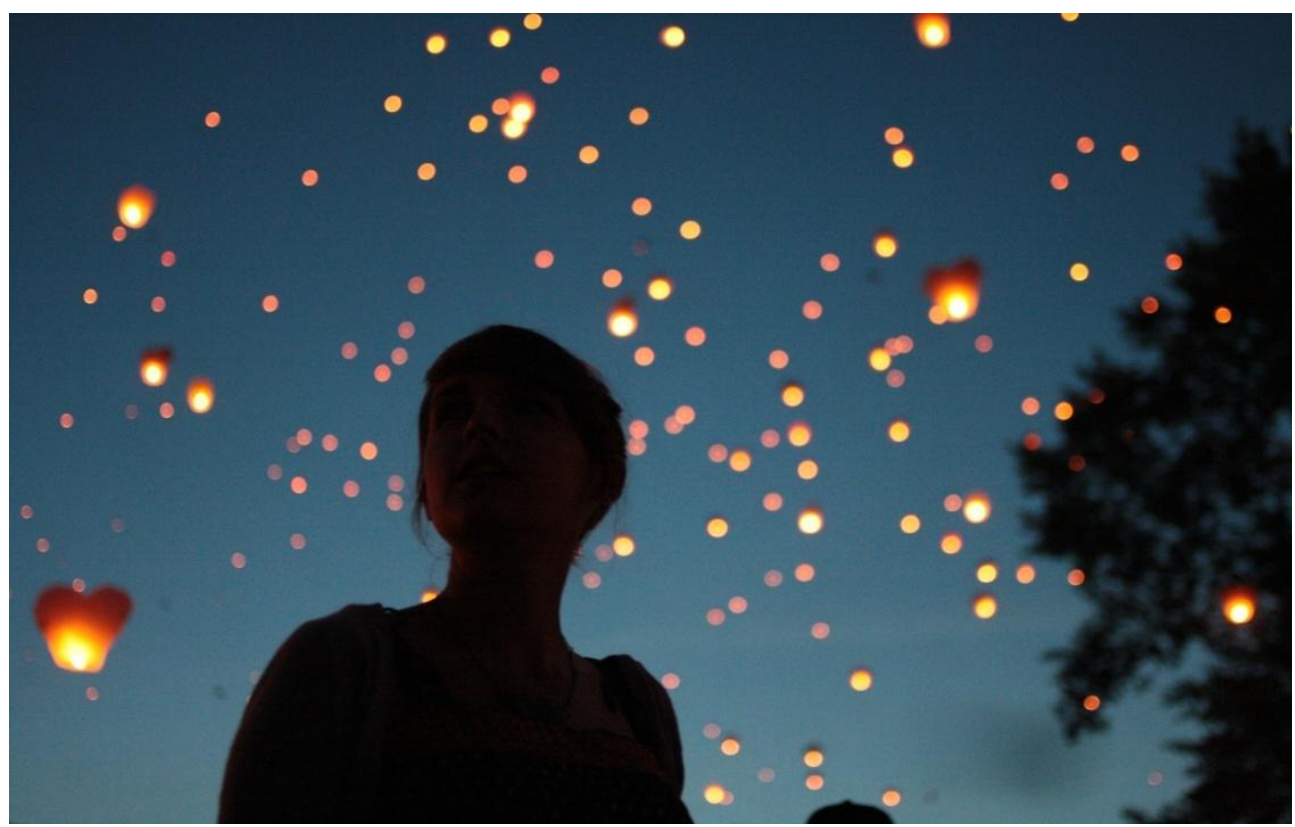

Celebrations honoring the Polish EU Presidency were staged in major cities across Poland. In Warsaw, a young Polish woman looks out on the thousands of lanterns that were released into the night on July 1 , 2011. Photo by Michael Anaya.

same time when Poland was at the helm of directing EU policy, the conditions were ripe for the Eastern Partnership to take center-stage. For Poland in particular, now was an opportunity to

\footnotetext{
${ }^{39}$ Olga Tomashevskaya, "Price of Freedom; Europe offered Belarus 3 billion euros," Vremya Novostei, November 3, 2010, 4.
} 
assert itself as a key player in the European Union and as a regional actor between Eastern Europe and the EU.

Poland assumed the Presidency of the Council of the European Union on July 1, 2011. Like all Member States, Poland will hold the Presidency for a six-month period. While President, Poland's responsibilities include chairing Council meetings and leading the Council (and the EU as a whole) through effective management strategy and mediation. ${ }^{40}$ The objective of the Presidency has changed since the adoption of the Lisbon Treaty; the duties of the Presidency are now divided and shared amongst the national Presidency and the permanent positions of Council President and High Representative. As a result, the Presidency in the formal sense does not have the power it once did, and is concerned more with technical and supervisory aspects.

Nevertheless, the Lisbon Treaty also guaranteed that co-decision procedure would be the standard of EU decision-making. In this regard, the Presidency's role as an intermediary between the various actors and institutions is essential to a well-functioning Union. ${ }^{41}$ The Presidency is an important equalizer amongst large and small, old and new Member States, and allows countries to set the tone of EU policy not only for that year but also for long-term programs and initiatives. While holding the Council Presidency is not as significant as it once was, it still affects the functioning of the EU and is a point of pride amongst individual European nation-states.

For Poland, the Presidency was an opportunity to showcase its leadership ability as well as demonstrate that it is a dynamic and prominent actor in the European arena. This was also an auspicious moment for the Eastern Partnership to gain attention and have the EU exact a comprehensive, cohesive, and above all effectual policy towards the region. Poland persistently argued for greater European involvement in the east, penned the Eastern Partnership initiative, and now was at the helm of a main European institution; given these circumstances, it was an optimal time for Eastern Europe to jump to the forefront of Europe's priorities.

In anticipation of the upcoming Council Presidency, the Polish government produced a list of six priorities for its 2011 Presidential agenda. Developing the EU's financial framework for 2014-2020 was at the top, followed by the Internal Market (particularly completing the single market in the service sector), the Eastern Partnership, EU's energy policy, Common Security and Defense Policy, and establishing a knowledge-based economy that would utilize Europe's

\footnotetext{
${ }^{40}$ Leszek Jesień, "The European Union Presidency" Polski Instytut Spraw Międzynarodowych, April 2011, 9.

${ }^{41}$ Ibidem, 13.
} 
intellectual resources. ${ }^{42}$ The diversity of these topics is impressive and, as in a national presidency, each one is intended to encapsulate a different policy field, be it economics, political cohesion, taking advantage of human capital, etc. Relations with Eastern Europe and the fruition of the Eastern Partnership, therefore, would be the principle component to the EU's foreign affairs dimension under the Polish presidency. Because of this, Poland highlighted the importance of neighboring countries to the welfare of the EU. For the last six months of 2011, Poland's intent in regard to third-party countries was to "extend the area of European values and regulations through... the development of cooperation with neighbouring countries, the promotion of European solutions at global forums, the building of deeper relations with strategic partners and a wise and effective development policy." ${ }^{43}$ Poland's list of priorities was admittedly ambitious. Nevertheless, the government of Poland was confident that these topics would be competently addressed during its Presidency.

\section{The Warsaw Summit and Belarus's withdrawal from the EaP}

The Eastern Partnership Summit, the premiere EaP meeting for 2011, was held in the middle of Poland's Presidential term. Heads of state, government representatives, and highranking officials from the European Union and EaP participant countries converged onto Warsaw during the last weekend in September to discuss the status quo of the Eastern Partnership and deliberate over the next step for the program. This Summit was the second one of its kind since the inauguration of the EaP, and with two years of the program's existence it was important to demonstrate progress and cite tangible results.

By the opening day of the Warsaw Summit, the Eastern Partnership could claim a number of successes. An Association Agreement with Ukraine was in its final stages of ratification. The establishment of a Deep and Comprehensive Free Trade Area with Ukraine, the first of its kind within Eastern Partnership territory, was announced a few weeks after the

\footnotetext{
${ }^{42}$ Krzysztof Śmiszek, "Equality and Non-Discrimination and the Priorities of the Polish EU Presidency," Heinrich Böll Stiftung, date accessed November 28, 2011, 2, http://www.boell.eu/downloads/Smiszek SoP final.pdf.

${ }^{43}$ Ministry of Foreign Affairs of the Republic of Poland, Programme of the Polish Presidency of the Council of the European Union (2011): 10, http://pl2011.eu/sites/default/files/users/shared/o prezydencja/programme of the polish presidency of the c ouncil of the eu.pdf.
} 
Summit concluded.$^{44}$ Moldova, Azerbaijan, Georgia, and Armenia are all in the negotiation process for Association Agreements. Moldova and Ukraine joined the EU Energy Community and are on the fast-track concerning future visa liberalization. Positive gains were made in the Eastern Partnership Civil Society Forum, an issue within the interest of both Poland and the European Union. Concurrent with the meeting in Warsaw, the Eastern Partnership Business Forum was launched in Sopot, targeting cooperation and dialogue within the private sector. Also launched was the Euronest Parliamentary Assembly which hopes to connect members of the EU Parliament with the parliaments of partner countries. The new Comprehensive Institution Building project aims to develop systems and regulations to be on par with those in the EU. The Eastern Partnership has and continues to expand from the confines of political and economic associations into the areas of energy, environment, local governments, civil society, and business. ${ }^{45}$ This increase in attention to Partnership countries has generally brought Eastern Europe into a closer relationship with the EU: "Political and economic reforms have been implemented in partner countries and relations between the EU and its Eastern European partners have deepened significantly. There is more trade and economic interaction between the EU and its Eastern European partners than ever before." ${ }^{46}$ To demonstrate the EU's support for the Eastern Partnership, the Union increased its financial contribution: "[President of the European Commission] Barroso revealed additional funds for further development of the $\mathrm{EaP}$ in the next multiannual financial framework for 2014-2020. Total financing of the Partnership has now reached almost $€ 2$ billion." ${ }^{47}$

It is important to recognize that progress has been made through the Eastern Partnership. However, from much of the analysis and information about it, the tone of the Warsaw Summit was decidedly phlegmatic. The primary dilemma facing a program like the Eastern Partnership is that the magnitude of the problems in Eastern Europe and the Caucasus is enormous.

Overcoming these institutionalized and deep-seeded issues is not something that can be

\footnotetext{
${ }^{44}$ Tadeusz Iwański, "Completion of Ukraine/ EU negotiations on DCFTA," Ośrodek Studiów Wschodnich, October 19, 2011, http://www.osw.waw.pl/en/publikacje/eastweek/2011-10-19/completion-ukraine/eu-negotiationsdcfta.

${ }^{45}$ Kerri Longhurst and Beata Wojna, "Asserting the EU's Mission in the Neighbourhood: Ten Recommendations for an Effective Eastern Partnership," Polski Instytut Spraw Międzynarodowych, September 2011, 8-10.

${ }^{46}$ Ministry of Foreign Affairs of the Republic of Poland, Joint Declaration of the Warsaw Eastern Partnership Summit, Warsaw, September 29-30, 2011, 1, http://www.msz.gov.pl/files/docs/komunikaty/joint declaration eap summit.pdf.

47 "Eastern Partnership Summit in Warsaw," last modified September 30, 2011, http://www.easternpartnership.org/publication/2011-09-30/eastern-partnership-summit-warsaw.
} 
accomplished after only two years. While this is acknowledged by everyone involved in the Eastern Partnership, there appears to be a general opinion that the outcomes to date have been underwhelming. From the Eastern perspective, many thought that there would be concrete agreements and treaties solidifying the supposed commitment of bringing the region within the European sphere. Instead, the rhetoric delivered at the end of the Summit was dominated by appeals for continued cooperation and work rather than actual achievements in the form of treaties and trade agreements. ${ }^{48}$ Conversely, on the European side, there was an expectation that partner states in Eastern Europe and the Caucasus would do more in their own countries to democratize. The political circumstances in this part of the world are still very volatile and significantly lacking in genuine democratic processes. Because of corruption and inconsistent commitment to good governance, the Eastern Partnership or any method of assistance is impeded.

Though the Warsaw Summit marked a number of gains and losses for other countries in Eastern Europe and the Caucasus, for Belarus it was another failure. Due to the 2010 presidential election and the enduring violation of his people's rights and freedoms, Lukashenko was not invited to attend the Warsaw Summit. The invitation instead went to Belarus's Foreign Minister, Serhiy Martynau. Martynau refused and in his place was designated the Ambassador of Belarus to Poland - he also backed out at the last moment. In a governmental capacity, Belarus was M.I.A. Despite Belarus's refusal, Brussels and Warsaw were not ready to give up on the country altogether. Addressing those at the Warsaw Summit, Polish Prime Minister Donald Tusk stated that if Lukashenko would fulfill certain reforms the European Union wanted, a $€ 9$ billion loan would be available for Belarus. ${ }^{49}$ This is three times as much that was offered the previous year. Despite the preposterously large amount of money offered, Lukashenko was unresponsive.

At the Summit a declaration was written voicing “deep concern” for Belarus's lack of reform as well as the frequent citations of human rights abuses. ${ }^{50}$ However, there was no recourse or consequence mentioned for Belarus, so the declaration was useless. The non-EU EaP

\footnotetext{
${ }^{48}$ Joint Declaration of the Eastern Partnership Summit.

49 "Tusk: EU ready to give Belarus up to 9 bn euro," last modified September 30, 2011, http://charter97.org/en/news/2011/9/30/43167/.

${ }^{50}$ Ministry of Foreign Affairs of the Republic of Poland, Declaration on the situation in Belarus adopted on the occasion of the Eastern Partnership Summit, Warsaw, September 30, 2011, http://www.msz.gov.pl/files/docs/komunikaty/20110930EAP/declaration_eap belarus.pdf.
} 
countries refused to sign the declaration, which gave the paper even less credibility. ${ }^{51}$ Based on research and analysis, the Eastern partners' reticence in speaking out against Belarus is mostly for fear that it would draw too much attention to their own governments' commitment to democracy. The fact that the EU, with all its influence, could not bring the EaP countries together and make a unified statement about Belarus was rather embarrassing to the EU and the Polish presidency. Even though the conclusion to the Belarus question at the Eastern Partnership Summit was flaccid, the Belarusian government began another campaign of rabble-rousing. Both Lukashenko and Martynau publicly chided the European Union for its discrimination against Belarus and for ignoring the founding principles of the Eastern Partnership. Taking offense to the European Union's position, Belarus quit the Eastern Partnership immediately following the Warsaw Summit. ${ }^{52}$

\section{Conclusions}

Before and after joining the European Union, Poland has been a repeated advocate for the European Union to invest more time and energy into Eastern Europe. Europe certainly saw the benefits of a stable and prosperous eastern flank. However, much of its interest (and therefore assistance) was focused on either more cooperative countries like Ukraine and Moldova, unstable and violent countries like the Balkans, or countries relevant for energy, market, or strategic concerns like Russia. In the priorities of the European Union, Belarus has often been the forgotten country in Eastern Europe. Europe took a harder line than Poland on Belarus from the beginning. While unfortunate, it is understandable that Belarus, a border country housing a Polish national minority, couldn't be ignored by Poland as easily as by the European Union.

Though the Belarusian government was inimical, aid in the form of technical assistance via the TACIS program and humanitarian relief was given by the European Union to Belarus. Because of this, the European Union was and continues to be a substantial donor to the country. However, the assistance granted to Belarus was impeded by a number of factors. Besides the obvious domestic barriers, the aid was too difficult to access. The application process was onerous, the rules were too constricting, and the report phase needed to be simplified. The

\footnotetext{
${ }^{51}$ Andrew Wilson, “The Warsaw Summit and Europe's 'New South'," last modified October 12, 2011, http://www.easternpartnership.org/community/debate/warsaw-summit-and-europe-s-new-south.

52 "Belarus quits Eastern Partnership initiative," last modified September 30, 2011, http://www.euractiv.com/europes-east/belarus-quits-eus-eastern-partnership-initiative-news-508050.
} 
projects that were funded by the EU were quite large and broadly-defined which hindered their implementation. The Union also did not capitalize on knowledge and information from local experts. The priorities of the aid were vague, and a general lack of transparency plagued the entire process. ${ }^{53}$

The successes and failures in Central and Eastern Europe made the European Union reevaluate its approach to the region, and from this the European Neighbourhood Policy came into existence. The ENP differentiated the territory surrounding the EU and took into account specific problems facing specific countries. In Eastern Europe and the Caucasus, the Eastern Partnership was initiated within the European Neighbourhood Policy to support lagging democracies and to boost weak economies. While the Eastern Partnership and the European Neighbourhood Policy have been more able instruments for the European Union in some respects, in Belarus it has still not produced any worthwhile results.

Based on my analysis, the EU's lack of success in instigating reform in Belarus is in part due to two prevailing issues. The first is the absence of any valuable leverage the EU can use against Belarus. One of the reasons Central Europe and the Baltic States were so successful as post-communist transition states was because there was a clear objective: joining the European Union. This goal was shared by both sides, and through demanding reform in exchange for privileges, the European Union exercised considerable influence over these countries' development. Because this "carrot and stick" approach worked well in countries like Poland and Estonia, the EU is recycling this formula, but without the explicit promise of EU membership. Unfortunately, by the EU isolating Belarus for so long, there are little political and social connections between the two that the Union can use to its advantage. The EU attempted to rectify this through inviting Belarus to be a part of the Eastern Partnership. However, the benefits of the EaP were inadequately defined and minimal, and the reforms demanded by the EU would be the death knell to Lukashenko's regime. Belarus has resigned from the Eastern Partnership and the EU is once again left with little bargaining power.

The second problem confronting the European Union in its relations with Belarus is its erratic policy towards the country and the regime. While the situation in Belarus has been in constant deterioration, the European Union's approach to Belarus has jumped around from isolation to partial engagement to a convoluted amalgamation of the two. The messages coming

\footnotetext{
${ }^{53}$ Rakava, 56-8.
} 
from European press releases and summits frequently do not correspond to the actions and events taking place. Even at the Eastern Partnership Summit in Warsaw, the European Union refused to invite Lukashenko while simultaneously offered him $€ 9$ billion to correct problems that he himself had created. This sort of muddled behavior sends a very mixed signal about the EU's intention and its objectives in Belarus.

Not only is the European Union's political intent contradictory within itself, it is even further disconnected by its economic policy; "From January 1993 to May 2005... [Belarusian] exports to the EU increased from $27 \%$ to $44 \%$ of total exports. ${ }^{~} 54$ In 2010 , The Netherlands received $11 \%$ of Belarusian exports, second only to Russia. ${ }^{55}$ Despite the political sanctions that are in place, the EU is still a substantial trading partner with a country it repeatedly censures for tyranny and oppression. The ineffective strategy is most aptly described by the "values/ security nexus" developed by Dr. Giselle Bosse from the University of Maastricht. Essentially, the European Union espouses magnanimous ambitions of liberating the downtrodden Belarusian population from tyranny and diffusing European principles to Belarus; EU resolutions and speeches are littered with references to championing democracy and promoting good governance in the authoritarian state. However, in regards to funding and the EU's primary concerns, democracy and freedom is often an afterthought to energy security and curbing cross-border traffic and illegal immigration. ${ }^{56}$ Until now, the European Union as a whole has not been able to devise a uniform strategy towards Belarus, and as a result the EU cannot make any sort of headway toward the country's reform and democratization.

Though the European Union has been ineffective in changing the political situation in Belarus, the European Union directly and indirectly has developed an appealing image for Belarusian citizens. Belarusians, particularly young Belarusians, are an increasingly mobile population and many work, travel, or study in the west. ${ }^{57}$ The majority of the Belarusians would like to see closer cooperation with Europe compared to Russia. This feeling is especially strong with those involved in the private/ business sector as western companies typically abide by a

\footnotetext{
${ }^{54}$ European Neighbourhood and Partnership Instrument Belarus, 12.

55 "ClA World Factbook: Belarus- Economy."

${ }^{56}$ Bosse, 223-224.

57 Mariusz Maszkiewicz, ed., Belarus-Towards a United Europe (Wrocław: Jan-Nowak Jeziorański College of Eastern Europe, 2009), accessed October 24, 2011, 5, http://www.robertschuman.eu/doc/actualites/1druk_eng_2009_p.pdf.
} 
higher code of ethics than Russian businesses ${ }^{58}$ If given the opportunity, Belarusians would like to foster stronger bonds with Europe.

Poland has expressed the opinion that the European Union needs to pay more attention to Eastern Europe. In the chapter detailing Polish-Belarusian relations, it was explained that on more than one occasion Poland's policy towards Belarus has been out of sync with that of the European Union. Nowadays, instead of acting independently, Poland is using its position as an EU Member State to convince Brussels and others to rally around Eastern Europe. In the Union's recent strategy towards Eastern Europe, democracy, good governance, and supporting civil society are featured much more than before. These topics have been components of Poland's objective in Eastern Europe for some time now, so this surge of interest on behalf of the EU is indicative of Poland's influence on the Union's external affairs. The Eastern Partnership is by far the best example of Poland's politicking between the European Union and the east. Successfully bridging the east with the west was not only in the interest of the respective parties, but is also beneficial for Poland. Successful sponsorship of an EU initiative would certainly give Poland substantial clout in the European Union. In addition, with Poland being one of the countries on the easternmost border of the EU, it has reaped other rewards for the EaP. The country has received millions of euros in order to facilitate the Comprehensive Institution Building and Cross-Border Cooperation programs. ${ }^{59}$ In addition to the Warsaw Summit, a number of forum meetings have taken place in a number of Polish cities. This is not only good public relations but generates revenue for Poland's tourism industry.

Progress within the Eastern Partnership was evident and more money was allotted, but the enthusiasm felt towards the initiative varied. Multiple factors contribute to the lackluster results. The democratic consolidation of the countries in the region has been moderate at best. Even Ukraine, the most promising state in Eastern Europe, has been butting heads with European officials due to the Yulia Timoshenko trial. Furthermore, the countries in Eastern Europe were competing for attention and resources with the more "exciting" democratic revolutions occurring in North Africa and the Middle East. The worsening economic crisis sweeping over Europe has

\footnotetext{
${ }^{58}$ Andrey Lyakhovich, "Belarus' Ruling Elite: Readiness for Dialogue and Cooperation with the EU," BelarusTowards a United Europe, 75.

59 "Eastern Partnership," last modified June 12, 2010, http://www.msz.gov.pl/Eastern,Partnership,Восточное,партнерство,19898.html.
} 
added insult to injury. Currently, Europe is looking more southward and inward than towards the east.

The Polish Council Presidency was determined to tackle a wide array of issues, the Eastern Partnership being only one of them. While the Warsaw Summit did not satisfy the expectations of some, Poland used this opportunity to reinvigorate, refocus, and re-strategize EU aspirations for the east. Perhaps due to the more difficult and long-term aims of good governance or civil society building, Poland as well as the EU emphasized the "contacts between people" pillar and the opportunities for visa-free travel between countries. This was a wise move on behalf of the Polish Presidency. Visa liberalization is one of the more attainable goals of the Partnership, particularly for the near future, and it is one of the most popular deliverables to all those involved. The Civil Society Forum and the Business Forum also have potential to reach out to different sectors of the population that maybe are less engaged with politics and diplomacy and could be a positive way to bypass some of the barriers imposed by the relatively illiberal political systems still prevalent in Eastern Europe.

Belarus is no longer a participant in the Eastern Partnership. In addition, in a recent closed parliamentary session the Belarusian government gave the KGB almost limitless power as well as restricted any NGO or opposition group from holding a foreign bank account or receiving assistance from abroad. ${ }^{60}$ Lukashenko is suffocating any threat to his power that exists within his country. The EU and Poland have tried repeatedly, but the situation now seems as bleak as ever-what should be the next course of action regarding Belarus?

\footnotetext{
60 "Secret amendments to laws: all are criminals and spies now?," last modified October 13, 2011, http://charter97.org/en/news/2011/10/13/43580/.
} 


\section{CONCLUSION: A EUROPEAN FUTURE FOR BELARUS? Recommendations for Poland and the EU in future assistance to Belarus}

This thesis has examined Poland and the European Union's relationships with Belarus as well as their respective reactions to the deteriorating situation concerning human rights and democratic governance occurring within the country. One of the objectives of such an analysis is to explore the ability of Poland, a post-communist state with close ties to Eastern Europe, to influence the EU's policy towards the east. After careful research and consideration, this study's assessment of the outcome is mixed. Generally, since 2008 Poland has made strides in becoming a more salient intermediary between the EU and Eastern Europe. Countries like Ukraine and Moldova are growing closer to Europe in terms of both economic and political cooperation. Through the Eastern Partnership, a predominantly Polish initiative, the European Union has both an increased presence in the region and has postulated clearer goals for the eastern neighbors, such as Association Agreements and easing travel restrictions. Through business and civil society platforms affiliated with the Eastern Partnership, the European Union is engaging with more than just political figures and is now working with private and public sectors in Eastern Europe, the Caucasus region, and Central Asia. Attention to this region is as high as it has been since the collapse of the Soviet Union, and this interest has translated into tangible results.

Despite the progress made with some countries, there is still much work that has to be done in establishing democracy in Eastern Europe and strengthening bonds between the EU and the east; the most striking example of this is Belarus. After 20 years the EU and Belarus are still at odds, and Belarus continues to be in the grips of authoritarianism. Poland, Belarus's western neighbor and self-proclaimed champion of Belarus's struggle for democracy and human rights in Brussels, has also been unable to instigate reform in the country. Why have both Poland and the EU been unsuccessful in improving the situation in Belarus?

The EU and Poland's failure in Belarus is both endemic to the situation in Belarus and systemic of the European Union's ability to act unilaterally in matters of foreign policy. As demonstrated in the chapters of this thesis, the European Union and Poland's positions on Belarus have been out of sync for too long. A united and unfaltering stance that combined Poland's (particularly Polish civil society) expertise with the European Union's power and 
resources could have made more of an impact. Instead, the response to Belarus has been haphazard and uncoordinated. In addition to the incompatible positions taken by Poland and the European Union, the political policies do not correspond with the economic policies. These inconsistencies weaken both Poland and the EU's ability to influence or encourage reform in the country. It must be noted, however, that this is not something that can be changed easily because at the heart of this problem is the absence of a single Common Foreign Security Policy within the European Union's external action framework. The European Union is, at its core, a zone of economic cooperation and trade that has evolved to be a supranational institution; in the past foreign relations and external policy were conducted by national governments through preexisting diplomatic forums (such as the UN) or, for defense, multilateral frameworks (such as NATO). ${ }^{61}$ To meet the demands of the European Union as a global actor, this is gradually changing. As mentioned in the introduction to this thesis, the Treaty of Amsterdam installed the idea that the Union adopting a Common Foreign Security Policy, which is essential to fulfill the mounting responsibilities of the Union in the world. Also, the European Union's pillar structure, a significant factor standing in the way of the EU adopting a comprehensive CFSP, has been abolished as part of the Lisbon Treaty. ${ }^{62}$ Though the Union is slowly adopting more flexibility to act in matters of foreign policy, external relations remain within the competences of the Member States, and there exists a reluctance to surrender this type of sovereign authority to a supranational body. At the time of writing this thesis there is no clear answer as to if, when, or how these institutional discrepancies will be rectified. Given the current circumstances, what can the EU and Member States do for Belarus, and what is the future outlook of the situation in Belarus?

\section{Lukashenko's future as the president of Belarus: prolonged but in peril}

As this thesis has shown, Lukashenko's foreign policy has bounced back and forth between Russia and the European Union. Though this flip-flopping makes Lukashenko seem erratic, one factor in Lukashenko's foreign policy has remained constant: Lukashenko will do anything, and cooperate with anyone, in order to maintain power. While in the past he has successfully played

\footnotetext{
${ }^{61}$ William Wallace, "Foreign and Security Policy: The Painful Path from Shadow to Substance" in Policy Making in the European Union, ed. Helen Wallace, William Wallace, and Mark A. Pollack (Oxford: Oxford University Press, 2005), 429-433.

${ }^{62}$ Robert Dover, "The EU's Foreign, Security, and Defence Policies" in European Union Politics, ed. Michelle Cini (Oxford: Oxford University Press, 2007), 240-41.
} 
the European Union and Russia against each other to stay in control, this is no longer the case. In the first chapter of this thesis, Belarus's historical relationship to its neighbors was described as being between a rock and a hard place. Similar to his country's history, President Lukashenko is caught between both international and domestic pressure that compromise his power in a way he has never before experienced.

When Lukashenko seemed more willing to work with the European Union starting in 2008, Brussels backed off some of its demands for reform. After the 2010 presidential elections, however, the European Union learned the hard way that any concessions made to Lukashenko will not coax him towards reforming Belarus, and instead only appease his harsh rule. Therefore, it appears as if the EU is only willing to negotiate with Lukashenko if all of its demands are met. An example of this is the release and rehabilitation of all, not some, political prisoners in Belarus. Not only do these conditions apply to Belarus's relationship with the EU, but also to institutions such as the IMF and the World Bank in which EU countries have extensive leverage. Essentially, the EU has wised up to Lukashenko, and it's going to be extremely difficult if not impossible for him to receive any loans or assistance from western organizations if the conditions in Belarus do not change.

When the west turned its back to Lukashenko, he could always turn to Russia as an ally and a benefactor. However, the relationship between Minsk and Moscow is not the same as it once was. Being that Belarus is an unreliable economic partner, Russia is also demanding certain stipulations for Belarus if Lukashenko wants to continue to receive assistance. Along with increased privatization, Russia also wants Belarus to adopt the Russian ruble as its official currency and sell the remaining shares of Beltransgaz to Gazprom. By ceding more power to Russia, Lukashenko runs the risk of losing his presidency, or at least becoming a puppet for Russian leaders that can be easily replaced if Moscow wills it.

Based on this author's research, Lukashenko has only managed to retain any popular support in his country because of two reasons: economic stability and security. Both of these have been severely crippled in 2011. Belarus is fueled both figuratively and literally by Russian oil and natural gas sold to refineries at discount prices. This allowed the economy, which has barely evolved since the days of the Soviet Union, to function despite its deep flaws. ${ }^{63}$ Now that Belarus

\footnotetext{
${ }^{63}$ Steven Woehrel, "Belarus: Background and U.S. Policy Concerns," last modified February 1, 2011, http://www.fas.org/sgp/crs/row/RL32534.pdf.
} 
is expected to pay Russian companies market prices for oil, it no longer retains the edge that kept its economy afloat. In 2011, cracks began to appear in Belarus's supposed "prosperous" economic model. Belarus's currency has devalued more than 50 percent since the government removed the fixed exchange rate. Reminiscent of the product shortages in the early 1990s, Belarusians were standing in long lines for days last spring to exchange rubles for dollars and euros. Because of rising inflation, Lukashenko has increased social benefits and pensions in order to placate Belarusian citizens and avoid mass dissent. However, with little money flowing from an unproductive economic system and the lack of foreign aid coming in from the outside sources, Belarus will undoubtedly go bankrupt. ${ }^{64}$

In addition to artificially shielding Belarus from economic hardship, Lukashenko also claimed to provide security to his citizens. However, Lukashenko has also lost considerable credibility in this regard. The violence following the December presidential election, sparked by the aggression of authorities, was hardly an example of maintaining peace in the country. In April of 2011, a terrorist attack on a Minsk subway left thirteen people dead and many more injured. While there are no immediate threats abroad, Lukashenko's behavior in the world has left him and his country with very few friends and even more enemies in the international community. Though Lukashenko has for years relied on his citizens feeling safe within their country to keep himself in power, nowadays Belarusians are neither personally nor financially secure.

The situation in Belarus is not sustainable. Lukashenko has very few options at this point, and regardless of what he does or does not do, his role as president of Belarus is in jeopardy. Since the violence following the elections in 2011, Lukashenko has further clamped down on opposition movements, civil society, and greatly expanded the powers of the secret police. In this author's opinion, this behavior is not out of malevolence but out of fear. Lukashenko is keenly aware of his unpopularity and growing unrest in his country, and as a result is lashing out in every direction, desperately trying to suppress any opposition to his power. Predictions in international relations are always difficult to make. In the case of Belarus, there exist two wild cards: Russia and Lukashenko. The actions of either could change the situation entirely. In reality, since the European Union and Russia are both growing weary of Lukashenko, the

\footnotetext{
${ }^{64}$ Kamil Kłysiński, "Systemic crisis in Alexander Lukashenko's regime," last modified October 28, 2011, http://www.osw.waw.pl/en/publikacje/osw-commentary/2011-10-28/systemic-crisis-alexander-lukashenkosregime.
} 
adoption of a common position by both Moscow and Brussels would potentially be the most effective strategy in dealing with Lukashenko. However, because of the absence of a concrete Russia policy taken by the EU as well as Russia's recent fraudulent parliamentary elections, the odds of this happening are slim. Regardless, if the European Union holds its ground on human rights improving in Belarus, and if Russia does not come to the aid of Lukashenko as it has in the past, Lukashenko's years as president are numbered.

\section{Prospective programs for facilitating democratization in Belarus}

The situation in Belarus cannot be solved exclusively from abroad. Belarusians must take the problems of democratization and good governance into their own hands for there to be real and long-lasting change. However, after extensive research and analysis of the current debates taking place in Europe, there are a number of options the European Union can take to aid democratization in Belarus, all of which can be achieved with Poland's support.

One of the most promising instruments in facilitating democratization in Belarus would be the establishment of a European Endowment for Democracy (EED). The idea for a European Endowment for Democracy was inspired by the United States' National Endowment for Democracy and would serve as a framework to promote democracy and good governance that correlate with European standards. A European Endowment for Democracy could correct the two persistent problems that currently exist in delivering assistance to democracy around the world: flexibility (given the rigidity of current European institutions) and the annual grantmaking calendar (a dilemma mentioned by one of the interviewees for this thesis). Also, creating an endowment that would exclusively focus on democratization would free up other organizations, such as the European Instrument for Democracy and Human Rights, to focus on matters relating to international development and addressing human rights abroad. The idea for the EED was proposed by Sikorski in order to provide a platform within the European Union that specifically addresses democratization, something important for both Polish and European foreign policy. ${ }^{65}$ The establishment of the Endowment would be a great step not only for the European Union but also a success for Poland at the EU level. However, for a European Endowment for Democracy to flourish, there are two elements that need to be taken into

\footnotetext{
${ }^{65}$ Kinga Brudzińska, "EU Democratisation Policy-Prospects for Establishing the European Endowment for Democracy," last modified October 7, 2011, http://www.pism.pl/index/?id=859bf1416b8b8761c5d588dee78dc65f.
} 
consideration. The first is to avoid redundancy. "Democratization" can be a vague term, and there are already a number of think tanks, foundations, and EU departments that work with components of democracy, such as formulating political parties and election monitoring. The EED should make its directives clear and its intentions specific enough to avoid duplication with other similarly-minded initiatives or projects taken on by the Union or other Member States. ${ }^{66}$ Additionally, Poland and the European Union must find an appropriate time to launch the Endowment. While the idea of creating the EED has received popular support in Europe, particularly from such important actors like France and Sweden, given the current economic situation Member States are not exactly enthusiastic about contributing more money to European projects, particularly ones that to some may not be seen as "pressing" or "urgent." While the Polish government is eager to get the EED underway during their EU Presidency, if the process for starting the Endowment is rushed through without it being well-planned and lacking panEuropean support, it is not going to succeed. The Polish government is the most ardent supporter of the EED, but it is going to require a certain sharpness and political finesse on behalf of Poles to make the Endowment a reality.

Given the situation in Belarus, unfortunately democracy is not going to be possible as long as Lukashenko is president. As explained before, how long he will have left as president remains to be seen. Nevertheless, given the current circumstances Poland and the European Union only have so much room to maneuver as external actors. At the moment, both Poland and EU should focus on visa liberalization for Belarusian citizens and expanding scholarship opportunities for Belarusian students. Future generations are going to be essential to Belarus's inevitable democratic revolution; perhaps the Vaćlav Havel or Lech Wałęsa of Belarus is sitting in a lecture hall in Kraków or Poznań learning the tenants of a functioning and thriving democratic system. Through studying abroad Belarusians can also become more exposed to western democracies as well as develop personal and professional contacts abroad. Countries like Poland would be ideal candidate countries for these types of opportunities because of their geographic proximity to Belarus (aka less expensive to travel) and for the lower cost of living compared to Western European countries.

\footnotetext{
66 "How Could a European Endowment for Democracy Add Value?," last modified September 2011, http://www.soros.org/initiatives/brussels/articles publications/publications/eed-paper-20110927/eed-paper20110927.pdf.
} 
A number of experts on Belarus have proposed ostracizing Lukashenko but engaging with other members of the Belarusian government as one method of dealing with the Belarusian government. By isolating the leader but cooperating with other "technocrats," western governments make valuable allies in the current regime that could prove useful during any future transition. A similar strategy was used effectively in Europe's response to Slobadon Milošević in Serbia. Also, these figures not only hold prominent positions in the Belarusian government but are many times within Lukashenko's influential inner circle. ${ }^{67}$ Assessing certain high-ranking Belarusians on a case-by-case basis could prove to be helpful in achieving western objectives for a democratic Belarus, although Poland and the European Union must tread carefully when approaching these individuals. The most likely scenario would be that these technocrats would be successful in persuading Lukashenko to accept certain economic reforms and allow more privatization of Belarusian companies. While the direct and indirect consequences of implementing more free-market reforms in the Belarusian economy could contribute to an overall democratization of Belarus, the country runs the very real risk of these entrepreneurs taking advantage of the system and establishing an oligarchy similar to what exists in Russia and Ukraine. Therefore, it is in the opinion of the author that the European Union and Poland should work together in standing up against the tyranny of Lukashenko and reaching out to young Belarusians as well as Belarusian civil society through regional cooperative initiatives (like the Eastern Partnership) and through a flexible, well-developed endowment.

\section{Final Thoughts}

Within the context of Poland being an influential regional actor between the European Union and Eastern Europe (particularly Belarus), the true test of Poland's ability to bridge the two is just beginning. Belarus has drifted in and out of Brussels' agenda ever since the collapse of the Soviet Union. Because of Belarus's withdrawal from the Eastern Partnership, the current economic crisis in Europe, and the democratization that is occurring in other parts of the European Union, it is likely that once again Belarus is going to slip away from the consciousness of most Europeans, and as a result the situation will continue to vitiate. If Poland is the vanguard of Belarusian democratization and the champion of Belarus at the European level, it is imperative that Poland continues to keep the rest of Europe abreast with what is happening in

\footnotetext{
${ }^{67}$ Lyakhovich, 62.
} 
Belarus, and convince the European Union that the democratization of Belarus should continue to be a priority. Through a regional dynamic, democracy in Belarus can take one step closer to becoming a reality. 


\section{Projects funded by the Polish MFA through the special competition,}

\section{Support for Belarusian Society 2011}

\begin{tabular}{|c|c|c|}
\hline Organization & Project Title & $\begin{array}{r}\text { Grant Amount } \\
\text { (PLN) }\end{array}$ \\
\hline $\begin{array}{r}\text { Angelus Silesius Meeting } \\
\text { House }\end{array}$ & $\begin{array}{r}\text { Citizen education as a development tool for } \\
\text { social participation in Grodno }\end{array}$ & 124,165 \\
\hline $\begin{array}{r}\text { The Freedom and Democracy } \\
\text { Foundation }\end{array}$ & $\begin{array}{r}\text { "Heartland of free speech"- Belarusian media } \\
\text { watch }\end{array}$ & 250,390 \\
\hline $\begin{array}{r}\text { Helsinki Foundation for Human } \\
\text { Rights }\end{array}$ & Human rights education in Belarusian schools & 152,360 \\
\hline Happy Childhood Foundation & Social youth exchange initiative & 98,897 \\
\hline $\begin{array}{r}\text { Helsinki Foundation for Human } \\
\text { Rights }\end{array}$ & $\begin{array}{r}\text { Supporting activities of the international } \\
\text { committee for the control of human rights in } \\
\text { Belarus }\end{array}$ & 188,130 \\
\hline $\begin{array}{r}\text { Żuławski Association, } \\
\text { Department of Science and } \\
\text { Technology for Agriculture } \\
\text { Technology and Engineering } \\
\text { (Stare Pole) }\end{array}$ & $\begin{array}{l}\text { Support for the development of entrepreneurship } \\
\text { in agriculture in areas of rural Belarus }\end{array}$ & 503,838 \\
\hline $\begin{array}{r}\text { School of Public Administration } \\
\text { (Szczeczin) }\end{array}$ & Local development leaders in Belarus & 170,780 \\
\hline CASE Belarus & $\begin{array}{r}\text { The support of private passenger transportation } \\
\text { companies by activating passenger transport } \\
\text { association }\end{array}$ & 113,200 \\
\hline Legal Clinics Foundation & $\begin{array}{r}\text { Improving the quality of services provided by } \\
\text { Belarusian legal advisory offices }\end{array}$ & 57,750 \\
\hline $\begin{array}{r}\text { Foundation for European } \\
\text { Studies }\end{array}$ & Support of non-formal education in Belarus & 91,303 \\
\hline $\begin{array}{r}\text { Fundacja na Rzecz Dzieci } \\
\text { Zagłębia Miedziowego }\end{array}$ & $\begin{array}{r}\text { Support for scientists from Grodno in developing } \\
\text { international scientific contacts through } \\
\text { participation in international scientific events in } \\
\text { Poland and Belarus }\end{array}$ & 48,550 \\
\hline $\begin{array}{r}\text { Solidarity with Democratic } \\
\text { Belarus }\end{array}$ & $\begin{array}{r}\text { EU countries for supporting the opposition and } \\
\text { civil society in Belarus }\end{array}$ & 385,050 \\
\hline Sempre a Frente Foundation & Building bridges- partnership development! & 115,130 \\
\hline $\begin{array}{r}\text { Institute of Public Affairs } \\
\text { Foundation }\end{array}$ & $\begin{array}{r}\text { Partners in Europe: Warsaw-Brussels-Minsk. } \\
\text { Study visits on the theme of European } \\
\text { integration for Belarusian youth leaders of public } \\
\text { opinion }\end{array}$ & 146,835 \\
\hline For Our Freedom and Yours & Belarus and the EU- the ways of rapprochement & 265,080 \\
\hline Fundacja Swietego Mikolaja & $\begin{array}{l}\text { Music, theatre, and cinematographic workshops } \\
\text { for children and youth in Belarus }\end{array}$ & 90,450 \\
\hline Józef Mianowski Fund & $\begin{array}{l}\text { A foundation for the promotion of science: } \\
\text { scholarship program for Belarusian scientists }\end{array}$ & 142,240 \\
\hline $\begin{array}{r}\begin{array}{r}\text { Centre of Civil Education } \\
\text { Poland-Belarus }\end{array} \\
\end{array}$ & $\begin{array}{r}\text { Good practices of transborder journalism: } \\
\text { Poland-Belarus }\end{array}$ & 69,950 \\
\hline Young Artists Association & $\begin{array}{l}\text { "Towards the theatre": unknown art- initiatives for } \\
\text { the promotion of culture (in this: publishing artists }\end{array}$ & 200,195 \\
\hline
\end{tabular}




\begin{tabular}{|c|c|c|}
\hline & $\begin{array}{r}\text { publication) through the active support of } \\
\text { Belarusian organizations and social } \\
\text { organizations at the local level }\end{array}$ & \\
\hline $\begin{array}{r}\text { Jan Nowak-Jeziorański College } \\
\text { of Eastern Europe }\end{array}$ & Civil Grodno & 243,478 \\
\hline Lazarski University & $\begin{array}{r}\text { Larzarski University Belarusian scholarship } \\
\text { program }\end{array}$ & 102,900 \\
\hline $\begin{array}{r}\text { Community Development } \\
\text { Society (Płużnica Municipality) }\end{array}$ & $\begin{array}{r}\text { Best Polish experience in supporting local } \\
\text { entrepreneurship e and micro-entrepreneurs } \\
\text { association }\end{array}$ & 124,780 \\
\hline $\begin{array}{r}\text { Solidarity with Democratic } \\
\text { Belarus }\end{array}$ & $\begin{array}{l}\text { "National solidarity" integration campaign for } \\
\text { active representatives of civil society in Belarus }\end{array}$ & 267,600 \\
\hline $\begin{array}{l}\text { ZHP (Polish Scouting and } \\
\text { Guiding Association) }\end{array}$ & Białystok: from 270 & 59,650 \\
\hline The New Media Foundation & DEMO! Democracy-Education-Media-Civics & 96,758 \\
\hline $\begin{array}{r}\text { Robert Schuman Foundation of } \\
\text { Poland }\end{array}$ & $\begin{array}{l}\text { Trip to Europe: guide about travel opportunities } \\
\text { and science in Europe for Belarusian citizens }\end{array}$ & 45,150 \\
\hline $\begin{array}{r}\text { East European Democratic } \\
\text { Association }\end{array}$ & $\begin{array}{r}\text { Increasing access to independent information in } \\
\text { regions of Belarus }\end{array}$ & 696,320 \\
\hline Fundacja Rozwiń Skrzydła & Not near, but together & 83,480 \\
\hline $\begin{array}{r}\text { Institutum Orientalium } \\
\text { Foundation }\end{array}$ & $\begin{array}{r}\text { "Entrepreneurship in Belarus"- Polish } \\
\text { entrepreneurs for supporting local } \\
\text { entrepreneurship in Belarus }\end{array}$ & 295,100 \\
\hline Fundacja Rozwiń Skrzydła & Environmental Aid Club & 171,479 \\
\hline Polish Aid Foundation & $\begin{array}{r}\text { Journalism competition for local communication } \\
\text { problems }\end{array}$ & 178,440 \\
\hline Institute for Eastern Studies & $\begin{array}{r}\text { Association uniting small and medium-sized } \\
\text { companies to initiate the development sector in } \\
\text { Belarus }\end{array}$ & 193,160 \\
\hline TOTAL & & $5,772,588$ \\
\hline
\end{tabular}




\section{Bibliography}

Primary Sources:

"Belarus/ Poland: Harassment of Polish journalists and media continues." Reporters Without Borders. Last modified October 28, 2005. http://arabia.reporters-sans-frontieres.org/article.php3?id_article $=15452$.

"Belarus quits Eastern Partnership initiative." EurActiv. Last modified September 30, 2011. http://www.euractiv.com/europes-east/belarus-quits-eus-eastern-partnership-initiative-news$\underline{508050 .}$.

"Belarusian foreign minister interviewed on relations with EU, Polish minority." $B B C$ Monitoring Europe - Political Supplied by BBC Worldwide Monitoring. May 26, 2010 Wednesday. Date Accessed: 2011/10/06. http://www.lexisnexis.com.www.libproxy.wvu.edu/hottopics/lnacademic.

"Belarusian leader interviewed on coming election, ties with Poland, Russia." BBC Monitoring Europe - Political Supplied by BBC Worldwide Monitoring. November 10, 2010 Wednesday. Date Accessed: 2011/01/17. http://www.lexisnexis.com.www.libproxy.wvu.edu/hottopics/lnacademic.

"Belarusian leader rejects accusations of crackdown on Polish minority." BBC Monitoring Kiev Unit Supplied by BBC Worldwide Monitoring. May 23, 2010 Sunday. Date Accessed: 2011/10/06. http://www.lexisnexis.com.www.libproxy.wvu.edu/hottopics/lnacademic.

Belsat TV. “About Us.” Last modified 2010. http://belsat.eu/en/o_nas/.

Bildt, Carl. "The European Union Eastern Partnership, Energy Security and U.S.-EU Cooperation." Speech given at the Brookings Institution, Washington, D.C., November 2, 2009. http://www.brookings.edu/ /media/Files/events/2009/1102_EU_eastern/20091102_eastern_partn ership.pdf.

Chivers, C.J. "Europe: Polish-Belarussian Tensions Increase." The New York Times, July 28, 2005. Date accessed October 6, 2011. http://query.nytimes.com/gst/fullpage.html?res=9D00E4D9103FF93BA15754C0A9639C8B63.

“CIA World Factbook.” Central Intelligence Agency. Last modified November 15, 2011. https://www.cia.gov/library/publications/the-world-factbook/index.html.

Commission of the European Communities. European Neighbourhood Policy Strategy Paper. Brussels, 2004. http://ec.europa.eu/world/enp/pdf/strategy/strategy_paper_en.pdf.

Commission of the European Communities. Progress Report Republic of Moldova. Brussels, 2009. http://ec.europa.eu/world/enp/pdf/progress2009/sec09_514_en.pdf. 
Coordinating Unit for the European Union's TACIS Programme in the Republic of Belarus. "The National Coordinating Unit in Belarus is your reliable guide to EU assistance." Last modified 2011. http://cu4eu.net/en/.

Council of the European Union. Joint Declaration of the Prague Eastern Partnership Summit. Prague, 2009.

http://www.consilium.europa.eu/ueDocs/cms_Data/docs/pressdata/en/er/107589.pdf.

Delegation of the European Union to Belarus. “About Us.” Last modified 2011. http://eeas.europa.eu/delegations/belarus/about_us/welcome/index_en.htm.

Dempsey, Judy. "Belarus: Promises of Aid for Opposition," The New York Times, February 3, 2011. Date accessed: October 6, 2011.

http://www.lexisnexis.com.www.libproxy.wvu.edu/hottopics/lnacademic.

Dempsey, Judy. "Poles nourish ties to Belarus opposition; Warsaw isn't waiting for EU as it moves to pressure its neighbor." The International Herald Tribune, January 7, 2011. Date accessed October 6, 2011. http://www.highbeam.com/doc/1P1-188074059.html.

EaPCommunity. "Eastern Partnership Summit in Warsaw." Last modified September 30, 2011. http://www.easternpartnership.org/publication/2011-09-30/eastern-partnership-summit-warsaw.

EaPCommunity. "EU Financial Assistance to the EaP States." Last modified 2011. http://www.easternpartnership.org/programmes/general.

“EU supporting Ukraine's reforms with €470.05 million in 2011-2013." ENPI Info Centre. Last modified 2011. http://www.enpi-info.eu/files/publications/Ukraine\%20NIP\%202010.pdf.

European Commission. European Neighbourhood and Partnership Instrument Belarus- Country Strategy Paper 2007-2013 and National Indicative Program 2007-2013. Brussels, 2007. http://ec.europa.eu/world/enp/pdf/country/enpi_csp_nip_belarus_en.pdf.

European Union External Action Service. “About Us.” Last modified 2011. http://eeas.europa.eu/delegations/belarus/about_us/welcome/index_en.htm.

European Union External Action Service. "Chronology of bilateral relations." Last modified 2009. http://eeas.europa.eu/delegations/belarus/eu_belarus/chronology/index_en.htm.

European Parliament. European Parliament resolution of 15 January 2009 on the EU strategy towards Belarus. Strasbourg, 2009.

http://www.europarl.europa.eu/meetdocs/2009_2014/documents/depa/dv/depa_20100310_03_8_ /depa_20100310_03_8_en.pdf.

European Parliament. European Parliament resolution of 2 April 2009 on bi-annual evaluation of the EU-Belarus dialogue. Brussels, 2009. 
http://www.europarl.europa.eu/sides/getDoc.do?pubRef=-//EP//NONSGML+TA+P6-TA-2009-

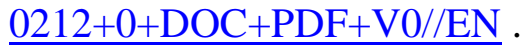

European Union Press Release RAPID. "Commissioner Benita Ferrero-Waldner visits Belarus to encourage further steps towards democratisation, assistance package of $€ 10$ mil announced." Last modified June 19, 2009.

http://europa.eu/rapid/pressReleasesAction.do?reference=IP/09/970\&format=HTML\&aged=0\&l anguage $=E N \&$ guiLanguage $=$ en.

Lepiarz, Jacek. "Poland wants to be the bridge between the E.U. and Belarus." Deutsche PresseAgentur. July 291998 Wednesday. Date Accessed: 2011/10/06.

http://www.lexisnexis.com.www.libproxy.wvu.edu/hottopics/lnacademic.

"Lukashenka at Bay." The Economist. December 12, 2010.

Ministry of Foreign Affairs of the Republic of Poland. Declaration on the situation in Belarus adopted on the occasion of the Eastern Partnership Summit. Warsaw, 2011.

http://www.msz.gov.pl/files/docs/komunikaty/20110930EAP/declaration_eap_belarus.pdf.

Ministry of Foreign Affairs of the Republic of Poland. "Eastern Partnership." Last modified June 12, 2010. http://www.msz.gov.pl/Eastern,Partnership,Восточное,партнерство, 19898.html.

Ministry of Foreign Affairs of the Republic of Poland. Joint Declaration of the Warsaw Eastern Partnership Summit. Warsaw, 2011.

http://www.msz.gov.pl/files/docs/komunikaty/joint_declaration_eap_summit.pdf.

Ministry of Foreign Affairs of the Republic of Poland. Poland's Development Co-operation Annual Report-2004. Warsaw, 2005. http://www.msz.gov.pl/files/docs/pomoc_pwr_en.pdf.

Ministry of Foreign Affairs of the Republic of Poland. Poland's Development Co-operation Programme Implemented through the Ministry of Foreign Affairs of the Republic of Poland 2011. Warsaw, 2011. http://www.polishaid.gov.pl/files/inne\%20dokumenty\%20PDF/Pomoc\%20zagraniczna\%202011 /Programme2011_PL.pdf.

Ministry of Foreign Affairs of the Republic of Poland. Programme of the Polish Presidency of the Council of the European Union. Warsaw, 2011. http://pl2011.eu/sites/default/files/users/shared/o_prezydencja/programme_of_the_polish_presid ency_of_the_council_of_the_eu.pdf.

Ministry of Foreign Affairs of the Republic of Poland. Strategy for Poland's Development Cooperation. Warsaw, 2003.

http://www.polishaid.gov.pl/files/dokumenty_publikacje/Strategy\%20for\%20Polands\%20Devel opment\%20Cooperation.pdf.

Nordlinger, Jay. “Belarus Assaulted.” National Review 63 (2011): 24-27. 
"Poland not to drop border traffic agreement with Belarus - foreign minister." BBC Monitoring Europe - Political Supplied by BBC Worldwide Monitoring. January 5, 2011 Wednesday. Date Accessed: 2011/10/06. http://www.lexisnexis.com.www.libproxy.wvu.edu/hottopics/lnacademic.

"Polish minister to push for uniform EU visa policy for all eastern neighbours," BBC Monitoring Europe - Political Supplied by BBC Worldwide Monitoring, May 11, 2010, date accessed October 6, 2011, http://www.lexisnexis.com.www.libproxy.wvu.edu/hottopics/lnacademic.

Polska Pomoc. "Białoruś- Projecty 2010.” Last modified August 23, 2011.

http://www.polskapomoc.gov.pl/files/Kraje\%20priorytetowe/BIALORUS_2010_lista\%20projekt ow.pdf.

Polska Pomoc. "Meeting of the Board of the Polish Know-How Foundation." Last modified July $1,2011$.

http://www.polskapomoc.gov.pl/Meeting,of,the,Board,of,the,Polish,Know,How,Foundation, 118 $\underline{0 . h t m l}$.

Polska Pomoc. "Wyniki Konkursu 'Pomoc Rozwojowa 2011'.” Last modified April 28, 2010. http://www.polskapomoc.gov.pl/Wyniki,konkursu,Pomoc,rozwojowa,2011,1048.html.

"Radosław Sikorski, Polish Foreign Minister, discusses innovation in foreign policy." The Belfer Center. Last modified April 25, 2011. http://www.youtube.com/watch?v=9T70pOJUbNc.

Ruselik, Valera. “Belarusian 'For Freedom' movement registered. What next?” Last modified December 19, 2008. http://humanrightshouse.org/Articles/9468.html.

"Russia Belarus Gas Pricing Row Sparks Jitters in Europe.” Deutsche Welle. Last modified December 29, 2006. http://www.dw-world.de/dw/article/0,2293767,00.html.

Studium Europy Wyschodniej- Universytet Warszawski. “Zasady Korzystania z 'Programu Stypendialnego im. Konstantego Kalinowskiego'.” Last modified 2011. http://www.studium.uw.edu.pl/_filez/Regulamin\%20Programu\%20im\%20\%20Konstantego\%20 Kalinowskiego.pdf.

Tomashevskaya, Olga. "Price of Freedom; Europe offered Belarus 3 billion euros." Vremya Novostei, November 3, 2010.

"Tusk: EU ready to give Belarus up to 9 bn euro." Charta 97. Last modified September 30, 2011. http://charter97.org/en/news/2011/9/30/43167/.

Zagranica Group. “About Zagranica Group.” Last modified 2011, http://zagranica.org.pl/en/Kim-jestesmy/.

Zwiądzek Polaków na Białorusi.“O Nas.” Last modified 2010. http://zpb.org.pl/node/1. 
Secondary Sources:

Balmaceda, Margarita M., James I. Clem, and Lisbeth L. Tarlow, editors. Independent Belarus: Domestic Determinants, Regional Dynamics, and Implications for the West. Cambridge: Harvard University, 2002.

Bosse, Giselle. "Challenges for EU governance through Neighbourhood Policy and Eastern Partnership: The Values/ Security nexus in EU/ Belarus Relations." Contemporary Politics 15 (2009): 215-227.

Brudzińska, Kinga. "EU Democratisation Policy—Prospects for Establishing the European Endowment for Democracy.” Polski Instytut Spraw Międzynarodowych. Warsaw, 2011. http://www.pism.pl/index/?id=859bf1416b8b8761c5d588dee78dc65f.

Burant, Stephen R. "International Relations in a Regional Context: Poland and its Eastern Neighbors-Lithuania, Belarus, and Ukraine.” Europe-Asia Studies 45 (1993): 395-419.

Burant, Stephen R. "Poland's Eastern Policy, 1990-95." Problems of Post-Communism 43 (1996): 48-54.

Cini, Michelle. European Union Politics. Oxford: Oxford University Press, 2007.

Copsey, Nathaniel and Karolina Pomorska. "Power and Influence in the European Union: Can New Member States Set the Policy Agenda?" Paper presented at the annual meeting of the American Political Science Association, Boston, Massachusetts, August 28-31, 2008.

Dean, Martin. Collaboration in the Holocaust: Crimes of the Local Police in Belorussia and Ukraine, 1941-44. New York: St Martin's Press, 2000.

Druker, Jeremy. East of Center: Transitions Online Regional Intelligence Editors' Blog. http://eastofcenter.tol.org/2011/08/and-now-poland-is-complicit-as-well/.

Garlicki, Andrzej. Jósef Pitsudski. 1867-1935. Hants: Scolar Press, 1995.

Gieysztor, Aleksander, Stefan Kieniewicz, Emanuel Rostworowski, Janusz Tazbir, and Henryk Wereszycki. History of Poland. Warsaw: PWN—Polish Scientific Publishers, 1968.

Gross, Jan T. Revolutions from Abroad, The Soviet Conquest of Poland's Western Ukraine and Western Belorussia. Princeton: University Press, 1988.

Haass, Richard N. "The Age of Nonpolarity: What Will Follow US Dominance?" Foreign Affairs, May/ June 2008.

"How Could a European Endowment for Democracy Add Value?" Open Society Institute. Brussels, 2011. http://www.soros.org/initiatives/brussels/articles_publications/publications/eedpaper-20110927/eed-paper-20110927.pdf. 
Iwański, Tadeusz. "Completion of Ukraine/ EU negotiations on DCFTA.” Ośrodek Studiów Wschodnich. Warsaw, 2011. http://www.osw.waw.pl/en/publikacje/eastweek/2011-1019/completion-ukraine/eu-negotiations-dcfta.

Jesień, Leszek. “The European Union Presidency.” Polski Instytut Spraw Międzynarodowych. Warsaw, April 2011.

Kłysiński, Kamil."Systemic crisis in Alexander Lukashenko’s regime.” Ośrodek Studiów Wschodnich. Last modified October 28, 2011. http://www.osw.waw.pl/en/publikacje/oswcommentary/2011-10-28/systemic-crisis-alexander-lukashenkos-regime.

Laufer, Pawel, editor. A Report of the Condition of NGOs and Independent Culture in Belarus. Lublin, Studio Format, 2011. Accessed October 17, 2011. http://kulturaenter.pl/pliki/pdfe/index.html.

Longhurst, Kerri, editor. Forging a new European Ostpolitik-An Assessment of Eastern Partnership. Warsaw: Collegium Civitas, 2009.

Longhurst, Kerri and Beata Wojna. “Asserting the EU's Mission in the Neighbourhood: Ten Recommendations for an Effective Eastern Partnership." Polski Instytut Spraw Międzynarodowych. Warsaw, September 2011.

Marples, David R. “Is the Russia-Belarus Union Obsolete?” Problems of Post-Communism 55 (2008): 25-35.

Marples, David R. "Outpost of tyranny? The Failure of Democratization in Belarus." Democratization 16 (2009): 756-776.

Maszkiewicz, Mariusz, editor. Belarus-Towards a United Europe. Wrocław: Jan NowakJeziorański College of Eastern Europe, 2009. Accessed October 24, 2011. http://www.robertschuman.eu/doc/actualites/1druk_eng_2009_p.pdf.

Padhol, Uladzimir M., and David R. Marples. "The 2010 Presidential Election in Belarus.” Problems of Post-Communism 58 (2011): 3-16.

Piletsky, Alexsandr. "The Belarusian-Polish Struggle." New Presence: The Prague Journal of Central European Affairs 12 (2010): 59-65.

Piotrowski, Tadeusz. Poland's Holocaust. Ethnic Strife, Collaboration with Occupying Forces and Genocide in the Second Republic, 1918-1947. Jefferson: McFarland \& Company, 1998.

Polonsky, Antony. Politics in Independent Poland 1921-1939. Oxford: Clarendon, 1972.

Pospieszna, Paulina. "When Recipients Become Donors.” Problems of Post-Communism 57 (2010): 3-15. 
Savchenko, Andrew. Belarus: A Perpetual Borderland. Leiden: Koninklijke Brill NV, 2009.

"Secret amendments to laws: all are criminals and spies now?" Charta 97. Last modified October 13, 2011. http://charter97.org/en/news/2011/10/13/43580/.

Śmiszek, Krzysztof. "Equality and Non-Discrimination and the Priorities of the Polish EU Presidency.” Heinrich Böll Stuftung. Date accessed November 28, 2011.

http://www.boell.eu/downloads/Smiszek_SoP_final.pdf.

Snyder, Timothy. Bloodlands: Europe between Hitler and Stalin. New York: Basic Books, 2010.

Snyder, Timothy. Reconstruction of Nations: Poland, Ukraine, Lithuania, Belarus, 1569-1999. New Haven: Yale University, 2003.

Wallace, Helen, William Wallace, and Mark A. Pollack, editors. Policy Making in the European Union. Oxford: Oxford University Press, 2005.

Wandycz, Piotr S. The Lands of Partitioned Poland, 1795-1918. Seattle: University of Washington Press, 1974.

Watt, Richard M. Bitter Glory: Poland and its Fate 1918-1939. New York: Simon and Schuster, 1979.

Wilson, Andrew. "The Warsaw Summit and Europe's 'New South'." Last modified October 12, 2011. http://www.easternpartnership.org/community/debate/warsaw-summit-and-europe-s-newsouth.

Woehrel, Steven. "Belarus: Background and U.S. Policy Concerns." Congressional Research Service. Last modified February 1, 2011. http://www.fas.org/sgp/crs/row/RL32534.pdf

Zaprudnik, Jan. Belarus at a Crossroads in History. Boulder: Westview, 1993.

Zaprudnik, Jan. Historical Dictionary of Belarus. Lanham: Scarecrow, 1998. 